\title{
DESIGUALDADE SOCIAL E DEMOCRACIA: O CASO BRASILEIRO E O LONGO CAMINHO EM BUSCA DE UMA SOCIEDADE DE IGUAIS
}

\author{
Giancarlo Montagner Copelli ${ }^{1}$
}

\begin{abstract}
Resumo
O presente estudo procurar analisar a desigualdade social no Brasil, projetando, a partir dos mecanismos de legitimação deste fenômeno, alternativas possíveis em busca de uma sociedade mais justa e igualitária, refletindo, portanto, um dos princípios que fundam o Estado Democrático de Direito. Para tal, este artigo está dividido em três partes: a primeira busca analisar o fenômeno da desigualdade a partir de sua relação com a democracia, regime em que se assenta o Brasil a partir do reordenamento jurídico proposto pela Constituição de 1988. A segunda parte observa a via democrática no Brasil diante de características como o populismo, presente neste regime a partir de meados dos Anos 1930 do século XX - com o crescimento em ritmo acelerado das grandes cidades -, e sua relação com a desigualdade social. Por fim, na terceira parte deste estudo, este artigo ensaia possibilidades de construção, a partir da própria democracia, de uma sociedade, de fato, composta por iguais. Para a realização da presente pesquisa, foi utilizado como método de abordagem o dedutivo, no qual se pretendeu partir da análise de categorias consideradas fundamentais para o desenvolvimento do tema - tais como elementos constitutivos da desigualdade social no Brasil - para então enfrentar o problema propriamente dito. Como método de procedimento utilizou-se o comparativo, buscando investigar as lacunas entre a democracia ideal e a democracia real. Como técnica de pesquisa aplicou-se a bibliográfica, baseada em documentação indireta, que serviu de base teórica para o desenvolvimento do estudo.
\end{abstract}

Palavras-chave: Desigualdade Social; Democracia; Populismo; Reconhecimento; Distribuição.

\section{INTRODUÇÃO}

A análise dos clássicos voltados à formação do Brasil, como A Formação Econômica do Brasil, de Celso Furtado (1959), A América Latina; Males de Origem, de Manoel Bomfim (2005), publicado originalmente em 1905, Os Donos do Poder, de Raymundo Faoro (2012), publicado pela primeira vez em 1958, O Povo Brasileiro, obra de Darci Ribeiro (2006), de 1964, ou A Formação do Brasil Contemporâneo e História Econômica do Brasil, de Caio Prado Júnior $(1963,1979)$ - e datadas, originalmente, de 1942 e 1945, respectivamente, além de Raízes do Brasil, de Sérgio Buarque de Holanda (1977), publicado inicialmente em 1936, entre outros, bem como de autores contemporâneos, como José Murilo de Carvalho (1987, 2002), com Os Bestializados e Cidadania no Brasil, respectivamente, ou a tese de livre-docência de Teresa Sales, Trama das desigualdades, drama da pobreza

\footnotetext{
${ }^{1}$ Mestre em Direito (Área de Concentração em Direitos Humanos) pela Universidade Regional do Noroeste do Estado do Rio Grande do Sul. E-mail: giancarlocopelli@yahoo.com.br
} 
no Brasil (1992), por exemplo, mostra o fenômeno da desigualdade social, em sua gênese, como o desencadeamento de uma série de fatores ligados às questões que envolvem um reconhecimento diferenciado entre os indivíduos que compunham a sociedade brasileira, à época de sua formação. Ou seja, as pessoas não eram vistas como iguais, mas diferenciadas através dos vínculos de pertença a um grupo, como negros, índios, mestiços e brancos, coletivizando o fenômeno e determinando posições sociais através de um status de origem.

A esse contexto histórico inicial, é somado, por sua vez, um novo contorno à desigualdade, alargando as diferenças entre os indivíduos a partir de meados dos Anos 1930, com a intensificação dos processos de industrialização no país: o acesso diferencial aos mecanismos capazes de permitir a reprodução da vida social, sobretudo em relação ao conhecimento ou às habilidades necessárias à incorporação no mercado laboral, restringindo, consequentemente, as possibilidades de atendimento das necessidades básicas das pessoas (SOUZA, 2009).

Destaca-se, nesse contexto, uma inversão nos traços constitutivos da desigualdade: se, antes, o problema era relacionado, principalmente, às questões atinentes a um reconhecimento diferenciado, que coletivizava a desigualdade, a partir da primeira metade do século XX tal fenômeno passa a ser, no Brasil, individualizado, amparado principalmente no mérito próprio de cada um, como se as possibilidades fossem idênticas a todos os estamentos sociais ou, ainda, como se não houvesse diferenças regionais significativas e, acima de tudo, como se o Sistema Educacional Público (onde a maioria dos brasileiros acessa os meios modernos de produção) oferecesse as mesmas possibilidades de formação de capital humano que o Privado. À luz da chamada Quarta Revolução Industrial, voltada à automação (MARQUES, 2010), a incorporação ao mercado de trabalho, cada vez mais restrita (POCHMANN, 1998), torna ainda mais evidentes estas disparidades, sobretudo a partir dos Anos 1980, agravando o problema.

Desses vieses acerca da desigualdade decorrem dois posicionamentos distintos. O primeiro, observando tal fenômeno através das lentes do passado, pondera a questão exclusivamente sob o enfoque dos contextos históricos brasileiros, de modo que a causa para a disparidade reside, nessa ótica, em um tempo de discriminação, marginalização e exploração próprias do Brasil Colônia, do Império e, a despeito da abolição da escravatura em 1888, também da Primeira República, ignorando, por sua vez, as causas atuais (ou mais imediatas), que impedem ou dificultam a reprodução da vida social, sobretudo a partir do mercado de trabalho.

O segundo posicionamento, por seu turno, percebe a desigualdade a partir do ângulo da redistribuição (sobretudo econômica, diante das dificuldades de incorporação no mercado de trabalho), mas não percebe a causa para esta necessidade, localizada no passado, mas sutilmente modificada no presente: a questão, embora redistributiva, permanece, ainda, um problema de reconhecimento distinto, já que os meios modernos de produção são acessados, com a anuência do Estado, de maneira diferencial na contemporaneidade, não obstante 
suas consequências. Bom exemplo, nesse sentido, é a formação de capital humano diferenciado através de escolas públicas e privadas - conforme bem demonstram os números do Ideb (MEC, 2014), e se observará ao longo deste texto. Tal diferença mostra-se como fator decisivo para, no futuro, influir nas restrições ao mercado (FERREIRA, 2000). Ora, se o Estado permite a apropriação diferenciada dos meios modernos de produção entre os indivíduos, reconhece, ainda que de maneira opaca, os indivíduos como diferentes, e não como iguais.

Reverter esse quadro, evidentemente, implica em percorrer um longo caminho, como acena Bobbio (2004), de maneira geral, acerca dos Direitos Humanos. Este longo caminho, por sua vez, passa, necessariamente, pela via democrática. Afinal, segundo este mesmo autor, é este o regime que se assenta sob o ponto de vista do direito, e não do poder. Contudo, em que pese o reordenamento jurídico proposto pela Constituição Federal de 1988, o Brasil é, ainda, um dos países mais desiguais do globo.

Assim, a questão que orienta este estudo volta-se ao paradoxo e às tensões contidas na relação entre a desigualdade e a democracia no Brasil, buscando alternativas possíveis para um sistema que reflita, enfim, uma sociedade de iguais, essência do próprio regime político em que se assenta o país.

Para tal propósito, este artigo está dividido em três partes: a primeira volta-se à relação entre a democracia e a desigualdade social, buscando compreender, a partir dos traços mais ou menos gerais desta forma política - bem como a partir de traços singulares da democracia brasileira - os pontos de encontro entre o regime e o fenômeno social aqui analisado. Já a segunda parte deste estudo observa a democracia e a desigualdade social sob o enfoque de características presentes no palco político brasileiro a partir de meados dos Anos 1930 do século XX, como o populismo (WEFFORT, 2003), buscando relações, ainda, entre essa espécie de deformidade da democracia e a desigualdade social. Por fim, na terceira e última parte deste artigo, este estudo ensaia possibilidades de superação dos paradoxos da democracia no Brasil, projetando, enfim, uma sociedade de iguais.

Para a realização da presente pesquisa, foi utilizado como método de abordagem o dedutivo, no qual se pretendeu partir da análise de categorias consideradas fundamentais para o desenvolvimento do tema - tais como elementos constitutivos da desigualdade social no Brasil, aqui observados como reconhecimento e redistribuição, por exemplo - para então enfrentar o problema propriamente dito. Como método de procedimento utilizou-se o comparativo, uma vez que se buscou investigar as lacunas entre a democracia ideal - um dever-ser - e a democracia real - um ser. Como técnica de pesquisa aplicou-se a bibliográfica, baseada em documentação indireta, que serviu de base teórica para o desenvolvimento do estudo. 


\section{A DESIGUALDADE SOCIAL E A DEMOCRACIA}

A desigualdade, seja tanto do ponto de vista político quanto do social, gozou de ampla aceitação ao longo da História da humanidade (BEDIN, 2002), e não foi uma característica apenas de regimes não democráticos, como as monarquias absolutistas, por exemplo. Mesmo em sistemas democráticos, como o modelo ateniense na Antiguidade - ou a República Romana -, a igualdade social não era um fim a ser alcançado, como bem pontua Dahl (2012), já que tais modelos pressupunham a igualdade apenas em relação à participação na vida pública, atrelando esta, por sua vez, à condição de cidadão².

Tal pensamento, ao excluir pela diferença, também foi reforçado pelas teorias platônica e aristotélica ${ }^{3}$, perpassando, através da tradição, "todo o período medieval" (BEDIN, 2002, p. 25), muito embora o Cristianismo, através do Catolicismo Romano, tenha defendido a igualdade perante Deus - mas não entre os homens ${ }^{4}$. E, mesmo após a Reforma Protestante ${ }^{5}$, que através da parcela que rompe com Roma formula as primeiras teses de igualdade entre os homens neste mundo (BEDIN, 2002)

A completa inversão entre desigualdade e igualdade, no entanto, somente se concretizou com os pensadores políticos do século XVII e XVIII. Foram eles ${ }^{6}$, portanto, os primeiros a sustentarem a ideia de igualdade entre os homens como um elemento constitutivo da nova sociedade [... A] defesa da igualdade no mundo moderno foi reconhecida também pelos legisladores que elaboraram as Declarações de Direitos de 1789 e de 1948, pois prescreveram no artigo primeiro de cada uma das declarações que todos os homens nascem livres e iguais em direitos e dignidade (BEDIN, 2002, p. 27 28 - colchetes nossos).

Desse modo, é possível verificar que a democracia, no sentido clássico ou antigo do termo, não pode ser associada à noção moderna de igualdade, ou seja, a dos pensadores políticos dos séculos XVII e XVIII. Afinal, conforme observado neste brevíssimo inventário da democracia na Antiguidade - através do exemplo da Grécia

\footnotetext{
${ }^{2}$ Conforme Dahl (2012, p. 32-33 - grifo nosso; parênteses do autor), a cidadania era condição exclusiva de homens nascidos em Atenas, filhos de pai e mãe atenienses, adultos. Crianças, mulheres, escravos e metecos, ou seja, estrangeiros, não eram considerados cidadãos: "A cidadania era, para todos os efeitos, um privilégio hereditário baseado em laços primordiais de família (embora a cidadania fosse privilégio herdado apenas pelos homens)". Para efeito deste estudo, a democracia, entretanto, será conceituada como um regime diferente do modelo grego, ou seja, como o regime que se coloca sob o ponto de vista do direito - e não do poder -, como bem pontua Bobbio (2000), e como aquele que presume igualdade entre os cidadãos em sentido pleno - e não apenas sob o enfoque político - como observa Rosanvallon (2012).

${ }^{3}$ Segundo Dahl (2012), Platão e Aristóteles, críticos da democracia, defendiam diferenças naturais entre os seres humanos.

${ }^{4}$ Importante, nesse sentido, a observação de Bielefeldt (2000, p. 149), demonstrando que, de fato, a igualdade pregada através do Cristianismo não se referia a este mundo: "Que a ideia da semelhança divina de todos os seres humanos não possa se condicionar ao reconhecimento de direitos iguais para todos, comprova-se pelo fato de a escravidão não ser questionada, em princípio, nem no Antigo Testamento nem no Novo Testamento".

${ }^{5}$ Souza (2009, p. 112 - grifo nosso; parênteses do autor) salienta, neste sentido, que, através do protestantismo, "a dupla moral (faça o que eu digo e não faça o que eu faço) típica das sociedades tradicionais, inclusive no Ocidente pré-moderno católico, que exigia trabalho dos inferiores para manter o ócio dos superiores (seja na sociedade como um todo, seja na Igreja), passa a ser duramente criticada como a suprema hipocrisia".

${ }^{6}$ Referindo-se, sobretudo, a Hobbes, Locke e Rousseau, muito embora, para o primeiro, do ponto de vista político, nem todos eram iguais, pois o soberano ficava fora - ou acima - do contrato.
} 
Clássica -, a igualdade era necessariamente vinculada ao conceito de cidadania que, como visto, era claramente seletivo. Somente a partir dos ideais que embasaram as chamadas Revoluções Liberais, como a Francesa, em 1789, e a Norte-americana, em 1776 - ou seja, após uma longa lacuna temporal que atravessa a Antiguidade e todo o Medievo - é que a igualdade entre os homens passou a ser considerada não somente uma das forças a promover tais revoluções, mas, sobretudo, a relacionar a noção de igualdade plena como indissociável da ideia de democracia, regime que então ressurgia cerca de 2.500 anos após a experiência grega. Neste sentido, segundo Rosanvallon (2012, p. 20 - aspas do autor):

Las revoluciones norteamericana y francesa, en efecto, no habían separado la democracia como régimen de la soberanía del pueblo y la democracia como forma de una sociedad de iguales. En L'Esprit de la Revolution de 1789, Pierre-Louis Roederer, una das grandes figuras de la Assemblea Constituyente, escribía específicamente: "El sentimiento que decidió el primer estallido de la revolución, el que excitó sus más violentos esfuerzos y obtuvo sus mayores éxitos, es el amor a la igualdad". "El primer motivo de la revolución - había resumido - fue la impaciencia por las desigualdades".

Assim - e ainda na esteira deste autor -, tanto a democracia enquanto regime político, ou seja, aquela associada à soberania popular e às liberdades civis e políticas, quanto a democracia enquanto sociedade de iguais não eram possibilidades díspares. Afinal.

Hay que se recordar que la igualdad e la liberdad, de buen grado presentadas hoy como antinómicas? , [...] eran compreendidas como indisociables en el momiento de la Revolución, siendo incluso na mayoría de las veces considerada la igualdad como matricial. En efecto, em 1789 nadie dudaba de que la igualdad fuera la "idea madre" o la consigna de adhesión del processo en curso. La misma cosa puede decirse de la Revolución Norteamericana. También es la idea de igualdad, junto con la de independencia, la que se constituyó en la clave de la cultura política de la época (ROSANVALLON, 2012, p. 21 - aspas do autor).

Entretanto, para Rosanvallon (2012), ao passo que o regime democrático passou a avançar sobre um número cada vez maior de nações no globo ${ }^{8}$, a partir das revoluções já citadas, alcançando, consequentemente, um contingente também cada vez maior de indivíduos sob esses mesmos valores, houve, contraditoriamente, uma espécie de ruptura com o passado recente: de um lado, a democracia, enquanto regime político, cresceu. De outro, as sociedades tornaram-se cada vez mais desiguais. Ou seja, a igualdade, para este autor, foi dissociada da liberdade, bem exercitada, sobretudo enquanto extensão dos direitos civis, no gozo de direitos políticos.

A constatação de Rosanvallon (2012), elaborada a partir do exemplo francês, também pode ser verificada no Brasil. Afinal, é possível observar um notável crescimento, ao longo da história, da participação dos

\footnotetext{
${ }^{7}$ Sen (s/d), em consonância com Rosanvallon (2012), também observa que, atualmente, há uma tensão, de fato, entre igualdade e liberdade no debate contemporâneo.

${ }^{8}$ Segundo Pinker (2013, p. 386), a "[...] Europa Meridional tornou-se totalmente democrática nos anos 1970, e a Europa Ocidental, no começo dos anos 1990. Atualmente, o único país europeu classificado como autocracia é Belarus, e todos, menos a Rússia, são democracias no pleno sentido da palavra. Também nas Américas e em importantes países desenvolvidos no Pacífico, como Coreia do Sul e Taiwan, predominam as democracias".
} 
cidadãos na política brasileira. Ou seja, é possível verificar o crescimento da democracia estritamente enquanto regime político e, paralelamente, constatar que o Brasil permanece como um dos países mais desiguais do mundo (BARROS et. al., 2007), coadunando sua condição, portanto, à observação de Rosanvallon (2012) acerca desta espécie de "paradoxo democrático" (SORJ, 2004, p. 13) em todo o mundo.

De fato, enquanto o Brasil apresenta significativas disparidades em diversas circunstâncias entre seus cidadãos, o país apresentou importantes avanços no que se refere aos direitos políticos, como se pode observar através da lição de Chaia (2010), ao inventariar a evolução do processo de participação política no Brasil', sobretudo, após o advento da República, em 1889.

Segundo essa pesquisadora, embora ainda fossem perceptíveis muitas restrições, houve, também, avanços na participação política ${ }^{10}$ : ao passo que não havia mais limitação de renda, como ocorria no Império, mulheres, menores de 21 anos, analfabetos, praças e religiosos enclausurados continuavam sem poder votar. Ou seja, ainda que muitos grupos fossem excluídos do processo, ao menos o exercício político do voto não era mais condicionado à renda, alargando, ainda que de forma muito discreta, o universo de eleitores.

Também de maneira pálida, a participação eleitoral avançou em 1932 e 1934, com o Código Eleitoral e a Constituição Federal, respectivamente: a idade mínima para a participação do processo eleitoral foi reduzida para 18 anos, e as mulheres - somente as que trabalhavam fora - passaram a exercer o direito ao voto, facultando, novamente, o alargamento do contingente de eleitores (CHAIA, 2010).

Do mesmo modo, embora tenha havido uma importante interrupção no avanço dos direitos políticos, de 1937 a $1945^{11}$, com a implantação do Estado Novo de Getúlio Vargas ${ }^{12}$, e por outra longa lacuna temporal, com a Ditadura Militar, de $1964^{13}$ até 1985 , ano que assinala a redemocratização do país, tais direitos continuaram

\footnotetext{
${ }^{9}$ Aqui, referimo-nos à participação dos cidadãos em relação ao voto como exemplo da ampliação da democracia enquanto regime político, também levando em consideração a definição de Bobbio (2000, p. 22), na qual por "regime democrático entende-se primariamente um conjunto de regras de procedimento para a formação de decisões coletivas, em que está prevista e facilitada a participação mais ampla possível dos interessados".

${ }^{10}$ Segundo Chaia (2010), logo após a independência em relação à metrópole portuguesa, em 1822, somente homens acima de 25 anos, com renda anual líquida de 100 mil réis - depois ampliada para 200 mil réis, em 1881 - eram considerados eleitores. O voto era censitário, havia uma série de limitações que estreitavam as possibilidades para ser candidato, e o imperador ainda decidia, a partir de uma lista tríplice, quais seriam os membros do Legislativo. A participação era, portanto, mínima.

${ }^{11}$ A partir de 1945, ocorrem algumas mudanças significativas na participação dos processos eleitorais e, também, muitos paradoxos podem ser observados. Bom exemplo é o fato de mendigos e analfabetos passarem a exercer direito a voto e, paralelamente, a condição de eleitor não depender apenas do alistamento nos Tribunais Regionais Eleitorais, mas também do preenchimento de um formulário nos locais de trabalho dos eleitores (CHAIA, 2010). Ora, mendigos não têm local de trabalho, e analfabetos não podem, evidentemente, preencher formulários.

12 "O argumento utilizado [...] era de que faltava capacidade e maturidade ao povo brasileiro e que somente esta elite política poderia representar e construir a nação brasileira. Todos os cargos eletivos foram eliminados, a escolha dos governadores e prefeitos passou a ser comandada pelo governo central, e o Poder Legislativo, em todas as esferas, foi fechado" (CHAIA, 2010, p. $03)$.

13 "Vários casuísmos foram criados para controlar o processo eleitoral: decretos-leis, atos institucionais, reformas no sistema partidário brasileiro, fechamento do Congresso Nacional, cassações, censura aos meios de comunicação, supressão dos direitos políticos, prisões e banimento políticos" (CHAIA, 2010, p. 04).
} 
a avançar e, a partir de 1989, data que marca a primeira eleição direta para presidente da República desde 1960, o voto já é livre, secreto, facultativo para cidadãos entre 16 e 18 anos de idade e maiores de 70 anos e analfabetos, e independente de gênero (CHAIA, 2010). Ou seja, tal direito, que muito bem pode representar o crescimento da democracia enquanto regime político, como predisse Rosanvallon (2012), passou a englobar um imenso contingente de cidadãos, não apenas se comparado aos sobressaltos autoritários de 1937 a 1945 e de 1964 a 1985, mas também em relação às possibilidades de participação política no Império, na Primeira República e no período democrático compreendido entre 1945 e o Golpe de 1964.

Contudo, de fato, tal crescimento da democracia, enquanto regime, não foi capaz de fazer do Brasil uma sociedade de iguais. Afinal, como bem observa Bedin (2006, p. 08), paralelamente ao avanço democrático, o Brasil permaneceu "um país [...] absolutamente injusto, tendo grande parte de seus cidadãos [...] em condições miseráveis, sem os recursos mínimos para uma existência com dignidade como pressupõe o Estado de Direito”. Assim, o Brasil mostra-se, paradoxalmente, como uma democracia, com um Estado de Direito consolidado ${ }^{14}$, mas não - ainda na esteira da análise de Rosanvallon (2012) - como uma sociedade de iguais.

Diante desse quadro - de democracia consolidada paralelamente à manutenção da desigualdade -, Sobottka (2009, p. 153) questiona-se:

A pobreza e a desigualdade social subsistem e, em muitos lugares, parecem inclusive estar aumentando. Chegamos ao ponto em que [...] aceitamos com alguma naturalidade que a questão proposta hoje para esta reflexão seja sobre quanta desigualdade a democracia pode suportar.

Para este autor, tal reflexão - que permite analisar as conclusões de Rosanvallon (2012) - denota duas possibilidades: 1) A resignação diante da desigualdade, ou seja, a percepção deste fenômeno social como um dado pronto e, por isso mesmo, natural e inevitável, restando saber, portanto, até que ponto se pode ser democrático e, paralelamente, desigual; e 2) A preocupação sobre a forma como as sociedades, em especial a brasileira, estão estruturadas, de modo que o foco do debate passa a ser, então, como se pode ser democrático e, ao mesmo tempo, desigual.

Naturalmente, a primeira possibilidade de análise desloca a ideia de igualdade do conceito de democracia, propondo necessariamente hipóteses voltadas a um limite que, ultrapassado, colocaria em xeque o próprio regime político. Contudo, se o Estado Democrático "é o tipo ideal de Estado de quem se coloca do ponto de vista do direito" (BOBBIO, 2000, p. 23), a resignação em relação à desigualdade implica não somente um fim,

\footnotetext{
${ }^{14}$ Bedin (2006, p. 06-07 - parênteses do autor; colchetes nossos), ao conceituar Estado de Direito como "[...] um Estado subordinado ao direito, que defende os direitos fundamentais e a segurança de seus cidadãos e que tem por base o princípio da razoabilidade, de responsabilidade por seus atos e do respeito da via judicial [e que,] Além disso, estrutura-se a partir da divisão dos poderes e da descentralização de suas atividades, sendo a sua administração orientada pelo princípio da legalidade e voltada à supremacia dos principios de liberdade e da igualdade, sem nunca afastar o fundamento popular do poder e a defesa do bem público", conclui seu acolhimento na estrutura jurídico-institucional brasileira: "Com efeito, a Constituição Federal em vigor no país define, de forma explícita, o Estado Brasileiro como Estado Democrático de Direito e o fundamenta na cidadania, no pluralismo político e na dignidade da pessoa humana (Art. 10)".
} 
mas também a conclusão de que a democracia é, nesse sentido, ineficaz, abrindo caminho para outras formas políticas que, invariavelmente, se colocam não mais do ponto de vista do direito, mas do poder (BOBBIO, 2000). De outra forma, é possível concluir, também, que tal análise não explica o distanciamento entre democracia e igualdade, como predito por Rosanvallon (2012), e tampouco busca alternativas para a superação deste paradoxo, mas justifica este distanciamento, encerrando esta espécie de antinomia como um axioma das sociedades modernas e democráticas.

De outra banda, analisar a questão proposta a partir da organização social - segunda alternativa de análise assinalada por Sobottka (2009) -, ao passo que faculta hipóteses que colocam a desigualdade como produto da dinâmica social - e não como uma causa absoluta a se resignar - permite analisar o fenômeno na gênese ou dentro da própria democracia, acenando, portanto, para uma contradição (SORJ, 2004). Esta, por sua vez, se observada como consequência da estruturação social, pode ser revertida ou pensada a partir do modelo democrático que, como visto, é, para Bobbio (2000), aquele que se coloca sob o ponto de vista do direito, e não do poder. Assim, se o núcleo da discussão volta-se à formação e à organização das sociedades, cumpre, portanto, recapitular, ainda que de maneira sintética, a estruturação social que deu forma ao modelo atual - ou moderno ${ }^{15}$ , como inscreve Sobottka (2009).

Desse modo, voltando necessariamente a atenção ao modelo idealizado e difundido a partir do século XVIII - enquanto ponto de partida para a compreensão das sociedades modernas -, importante a observação de Lefort (1991), ao destacar que tais conformações sociais moldaram e foram moldadas pela democracia, à medida em que se assentaram justamente na luta dos liberais contra as desigualdades e privilégios que caracterizaram o Antigo Regime. Sobottka (2009), em complemento à lição de Lefort (1991), ensina, por sua vez, que prevaleceu como fundamentação a essa inversão - do Antigo Regime ao modelo liberal ou moderno - o argumento de que todos os indivíduos eram naturalmente iguais ${ }^{16} \mathrm{e}$, por isso, assim deveriam ser reconhecidos socialmente ${ }^{17}$. Contudo, a igualdade, para este autor, foi observada apenas do ponto de vista formal, sustentando apenas o igual direito de ser livre:

\footnotetext{
${ }^{15} \mathrm{O}$ mundo moderno apresenta, segundo Sorj (2004), diferentes formas de sociedade e regimes políticos, como aqueles encontrados em países islâmicos, os sob o viés do comunismo, e os capitalistas, como as democracias liberais. É sobre este último modelo, considerado moderno, que nos referimos neste estudo.

${ }^{16}$ Para Bobbio (2004, p. 21), a fundamentação jusnaturalista ou "a ilusão de um fundamento absoluto, foi um obstáculo à introdução de novos direitos, total ou parcialmente incompatíveis com aqueles. Basta pensar nos empecilhos colocados ao progresso da legislação social pela teoria jusnaturalista do fundamento absoluto da propriedade: a oposição quase secular contra a introdução dos direitos sociais foi feita em nome do fundamento absoluto dos direitos de liberdade. O fundamento absoluto não é apenas uma ilusão; em alguns casos, é também um pretexto para defender posições conservadoras"

${ }^{17}$ Esse ideal, como vimos com Bedin (2002) anteriormente, precede o século XVIII e já se encontra nos discursos do século XVII. Bom exemplo vem de Dahl (2012, p. 48-49), ao relembrar um trecho do tratado An Arrow Against All Tyrants, de Richard Overton, um leveller britânico, em 1646: "Pois, pelo nascimento, todos os homens são iguais".
} 
Em decorrência disto, cabe a elas [as pessoas, consideradas iguais] escolher livremente como querem organizar sua vida em sociedade e quem deverá governá-las. A igualdade entre as pessoas e a soberania do povo foram concepções novas, fundamentais para a implantação da democracia como forma de livre escolha dos governantes. [Contudo,] dentro desse projeto, que prevaleceu sobre outras alternativas de organização social defendidas à época, o princípio estruturante último não é a igualdade nem a soberania do povo, e sim a liberdade individual que, para seus defensores, antecede e se sobrepõe a qualquer comprometimento solidário. Por isso, como mostrou Flinckinger $(2003)^{18}$, a igualdade é considerada somente no seu aspecto formal, e pode conviver sem qualquer constrangimento normativo com a desigualdade material das pessoas. Nesta sociedade tem importância que as pessoas sejam iguais perante a lei e que sejam computadas igualmente na hora de comparecerem às urnas eleitorais; mas não tem relevância ética alguma o modo como vivem o seu cotidiano - a menos que coloquem em risco o modo como outros querem viver seu cotidiano. Ser cidadão nesta sociedade é, sobretudo, ter o direito de viver sua liberdade sem riscos de ser importunado pelos outros e pelo Estado (SOBOTTKA, 2009, p. 154 colchetes e grifo nossos; parênteses do autor).

A partir da observação deste autor, é possível concluir a prevalência de um direito fundamental - a liberdade - sobre outro - a igualdade -, na base constitutiva das sociedades modernas, ou seja, daquelas estruturadas a partir do século XVIII e denominadas democracias. De outro modo, é possível dizer que o ideal de igualdade pôs abaixo o privilégio - de um único indivíduo ou de poucos - de decidir como se governa ou quem governa, criando prerrogativas idênticas entre os indivíduos em sentido político, alargando também a liberdade para se viver da maneira julgada mais apropriada ${ }^{19}$. Mas esse mesmo ideal de igualdade não visou pôr abaixo o privilégio que permitia condições diferenciadas - do ponto de vista material - para a vida em sociedade - muito embora fosse esse um ideal revolucionário no século XVIII, conforme Rosanvallon (2012) - favorecendo, portanto, a existência da desigualdade dentro de um regime democrático, sem constrangimentos, como assinala Sobottka (2009).

Assim, evidencia-se a coexistência de democracia e desigualdade como um paradoxo não apenas propriamente brasileiro, mas, sim, comum - em maior ou menor grau - a todas as sociedades modernas, fundadas a partir dos ideais liberais do século XVIII. Entretanto, sociedades, como a brasileira, por exemplo, ainda diferem daquelas consideradas centrais porque, naquelas:

O Direito cria uma igualdade formal entre todos os cidadãos [...] e estrutura o marco institucional tanto para as relações sociais particulares como para o governo, [comprometendo] todos os cidadãos e toda a nação a respeitar e a

\footnotetext{
${ }^{18}$ Referindo-se ao texto "A trajetória das políticas sociais na Alemanha, que compõe a organização intitulada Entre caridade, solidariedade e cidadania: História comparativa do Serviço Social Brasil-Alemanha”, organizada pelo mesmo autor e publicada pela Edipucrs, Porto Alegre, 2000.

${ }^{19}$ Esta última prerrogativa, para Touraine (2012, p. 345), não pode, na verdade, ser garantida, pois está entrelaçada ao mercado, e este "não garante nem a igualdade de oportunidade de todos, nem a orientação dos recursos para a satisfação das necessidades mais sentidas”. Entretanto, importante ressaltar que, segundo Sobottka, (2009), o Estado de Bem-estar Social, pela via política, busca, ainda que também com muitas limitações, alterar o equilíbrio desigual entre liberdade e igualdade.
} vol.08, nº. 03, Rio de Janeiro, 2015.pp. 1211-1243 
cumprir consequentemente os direitos e deveres inerentes à cidadania ${ }^{20}$ (SOBOTTKA, 2009, p. 154-159).

Embora não sejam exatamente exemplos de sociedades igualitárias, Sobottka (2009) refere, como apoio à sua afirmação, tal comprometimento a sociedades como a Alemanha, a França e a Inglaterra, países que, em tese, construíram espaços comuns - entre os indivíduos-cidadãos - para seus respectivos conceitos de cidadania ${ }^{21}$, por meio de noções pré-políticas, como pertinência étnico-cultural, ou relações jurídicas de pertinência ${ }^{22}$. Entretanto, no Brasil - bem como em outras sociedades periféricas -, tal igualdade formal, fruto da tradição liberal que funda as sociedades modernas sob o ideal democrático, não supôs, nas bases estruturantes destas mesmas sociedades (COSTA, 1987; SALES, 1992), o "sentimento de um destino comum" (SORJ, 2004, p. 22), ou seja, o caminho lógico da igualdade determinada pela cidadania, independentemente desta construção ocorrer por noções de pertinência pré-política ou pertinência jurídica. Ao contrário, consolidou:

Uma longa tradição de oferta de assistência para os necessitados ${ }^{23}$ com a busca de alguma renda em forma de privilégio decorrente de acesso ao Estado. A inclusão em relações de clientelismo ou compadrio certamente tem maior relevância que um comprovante de cidadania. A contemplação de direitos sociais de cidadania pouco alterou esta tradição (SOBOTTKA, 2009, p. 158).

Uma explicação possível para a afirmação acima, ao dar maior peso às relações clientelistas ou de compadrio em detrimento de direitos sociais - que em tese deveriam ser assegurados por vínculos de cidadania -, pode ser encontrada na forma de estruturação social do Brasil. Ou seja, somadas as características de formação das sociedades modernas, fundadas a partir dos ideais liberais do século XVIII, a "democracia inesperada", como inscreve Sorj (2004, p. 13), também decorreria de contextos muito próprios ${ }^{24}$. De fato, para Carvalho (2002), tais

\footnotetext{
${ }^{20}$ Cidadania, aqui, compreendida dentro do conceito de Sorj (2004, p. 22 - parênteses do autor), ou seja, "uma instituição que oferece um título de propriedade particular: um bilhete de entrada para uma comunidade nacional, que dá acesso a um conjunto de direitos - bilhete que se obtém mediante um sistema de critérios (por exemplo, local de nascimento ou nacionalidade dos pais) distribuídos pelo poder constituído", mas também alargada pelo Estado de Bem-estar Social, ou seja, o que para Sobottka (2009, p. 155 - colchetes nossos) constituía "esta nova concepção de direito [que] passou a legitimar a redistribuição, pela via política, de bens que o mercado, quando deixado à sua própria sorte, alocava de forma crescentemente desigual".

${ }^{21}$ Falamos em respectivos conceitos de cidadania por compreender que, embora haja uma delimitação geral, como a explicitada na nota de rodapé anterior, os conteúdos de tais conceitos são o resultado de construções históricas, variando, portanto, de um lugar ou país a outro (SORJ, 2004).

${ }^{22}$ Mesmo nas relaçôes jurídicas, Souza (2009, p. 400-401 - colchetes nossos) adverte que "a lei da igualdade só possui realidade efetiva nas sociedades que, a partir de uma mobilização social [equalizou as] condições das classes inferiores [...] Essa é a diferença que explica efetivamente a distância social de sociedades modernas periféricas como a brasileira e as sociedades modernas centrais". ${ }^{23}$ Longa tradição de oferta de assistência aos necessitados que, através da lição de Sobottka (2009), permite concluir que tais favores limitaram, historicamente, a noção de cidadania no Brasil, ao contrário do que deve ocorrer, em tese, com a ampliação de direitos sociais através do Estado de Bem-estar Social.

${ }^{24}$ Contextos compreendidos como a gênese da estrutura social brasileira. Referem-se ao fato de que, tal qual na Europa do século XVIII, os ideais liberais, aqui, também atenderam às demandas de uma elite já constituída, de modo que a independência da metrópole - em 1822, através da criação do Império Brasileiro - visou apenas à emancipação do fisco português, liberando, segundo Costa (1987), as massas do próprio processo de independência. Ou seja, a independência não foi nem do povo nem para o povo, mas, sim, de uma elite e para uma elite. Além disso, importante recordar que, com o advento da República, em 1889, o governo buscou igualmente atender às expectativas dos grandes proprietários (CARVALHO, 1987), de modo que o povo, constituído por indivíduos sem vínculos de cidadania, participou de "um projeto político-econômico que não fora por eles vol.08, no. 03, Rio de Janeiro, 2015. pp. 1211-1243 1220
} 
contextos, relacionados especificamente à gênese da sociedade brasileira, levaram a uma completa inversão na sequência dos direitos, segundo a lógica descrita por Marshall ${ }^{25}$, favorecendo as relações pessoais em detrimento dos vínculos de cidadania:

A cronologia e a lógica da sequência descrita por Marshall foram invertidas no Brasil. Aqui, primeiro vieram os direitos sociais, implantados em período de supressão dos direitos políticos e de redução dos direitos civis por um ditador que se tornou popular [Getúlio Vargas]. Depois vieram os direitos políticos, de maneira também bizarra [...] A pirâmide dos direitos foi colocada de cabeça para baixo (CARVALHO, 2002, p. 219-220 - colchetes nossos).

Este autor, embora defenda a existência de outros caminhos possíveis para a construção da cidadania, afirma que a inversão da pirâmide dos direitos afetou o tipo de democracia que se tem no Brasil, assinalando que, hoje:

Uma consequência importante é a excessiva valorização do Poder Executivo. Se os direitos sociais foram implantados em períodos ditatoriais, em que o Legislativo ou estava fechado ou era apenas decorativo, cria-se a imagem, para o grosso da população, da centralidade do Executivo. O governo aparece como o ramo mais importante do poder, aquele do qual vale a pena aproximar-se. A fascinação com um Executivo forte está sempre presente, e foi ela sem dúvida uma das razões da vitória do presidencialismo sobre o parlamentarismo, no plebiscito de 1993. Essa orientação para o Executivo reforça longa tradição portuguesa, ou ibérica, patrimonialismo. $\mathrm{O}$ Estado é sempre visto como todo-poderoso, na pior hipótese como repressor e cobrador de impostos; na melhor, como um distribuidor paternalista de empregos e favores. [...] Essa cultura orientada mais para o Estado do que para a representação é o que chamamos de "estadania", em contraste com a cidadania (CARVALHO, 2002, p. 221 - aspas do autor) ${ }^{26}$.

Por isso, Sales (1992, p. 35) afirma, nesse sentido, que "o domínio do liberalismo pouco contribuiu para a instauração dos direitos básicos de cidadania”, já que, historicamente, esses mesmos direitos sempre foram - e continuam sendo, muitas vezes ${ }^{27}$ - vistos como concessões, e não propriamente como direitos, comprometendo o:

Metafundamento social da cidadania moderna [que] é a dupla indivíduonação ou indivíduo-povo. O cidadão constitui-se como indivíduo por ser parte de uma comunidade dentro da qual se reconhece e é reconhecido como um igual (SORJ, 2004, p. 23 - grifo e colchetes nossos).

idealizado e do qual muito menos foram os maiores beneficiados" (VICENTINO, 1999, p. 147), de forma que qualquer traço de cidadania dependeu, desde o Brasil Colônia, exclusivamente do favor.

${ }^{25}$ Segundo Sorj (2004, p. 25), no modelo de Marshall “a cidadania teve como motor a expansão do ideal de igualdade jurídica para as esferas política e econômica. A igualdade perante a lei teria promovido a luta pela igualdade de condições de participação política, [...] e esta teria permitido o avanço dos direitos sociais".

${ }^{26}$ Observaremos, na próxima parte deste estudo, as consequências decorrentes desta observação de Carvalho (2002) de maneira mais detalhada.

${ }^{27}$ Carvalho (2002, p. 223-224) salienta que, hoje, "o papel dos legisladores reduz-se, para a maioria dos votantes, ao de intermediários de favores pessoais perante o Executivo. O eleitor vota no deputado em troca de promessas de favores pessoais; $\mathrm{O}$ deputado apoia o governo em troca de cargos e verbas para distribuir entre seus eleitores. Cria-se uma esquizofrenia política: os eleitores desprezam os políticos, mas continuam votando neles na esperança de benefícios pessoais". 
Evidentemente, o binômio aludido por Sorj (2004), em complemento à afirmação de Sales (1992), apresenta contradições que vão além destas peculiaridades. Afinal, os princípios que fundam a cidadania moderna - indivíduo e comunidade - "apresenta[m], desde suas origens, uma constante tensão" (SORJ, 2004, p. 27 colchetes nossos). E, por isso mesmo, compreender as características de formação social brasileira - como, entre outras, o clientelismo e essa percepção, como quer Carvalho (2002), de um Estado todo-poderoso, por exemplo - como causa exclusiva para uma espécie de déficit de cidadania no Brasil, ignorando as antinomias presentes nas demais democracias, levaria à confusão entre concepções ideais - um dever ser, geralmente associado, apesar das imperfeições já apontadas, aos países desenvolvidos, centrais - e contextos verificáveis, empíricos - um ser, longe da idealidade, comumente associados a países considerados periféricos, como o Brasil. Por isso, em que pesem nossas características próprias na formação social brasileira - enquanto contribuição para um déficit de cidadania -, não thes cabe, assim, uma exclusividade nesse sentido. Afinal, se têm importância as características próprias, pesam também as contradições inerentes a qualquer democracia.

Assim, é possível assinalar que a democracia, independente da sociedade em que se encontra, seja central ou periférica, convive tanto com contradições mais ou menos gerais ${ }^{28}$ quanto com paradoxos peculiares, e tanto a igualdade quanto a liberdade, bem como as questões que envolvem a cidadania, de modo geral, formam contextos centrais nesta discussão. Por isso, como já visto com Rosanvallon (2012) no início desta parte do estudo, se o ideal de igualdade vem, em todo o globo, se desprendendo do ideal de democracia, evidentemente essa espécie de tendência mundial - e negativa - também reflete no Brasil.

Contudo, se as características de formação social brasileiras não são responsáveis exclusivas pela desigualdade e por outros paradoxos democráticos, não se pode, igualmente, deixar de levá-las em consideração. Afinal, se os vínculos de cidadania - inclusive aqueles tênues, que não evitam altos níveis de disparidade entre os cidadãos - são construções históricas e ligados a cada sociedade em particular (SORJ, 2004), não se pode pensar tal fenômeno social nem somente a partir de uma tendência ou característica que afeta a totalidade das sociedades modernas, em especial as consideradas democráticas, nem apenas a partir das características peculiares a cada nação.

Assim, é possível chegar à conclusão inicial de que, no Brasil, pesou a antinomia entre igualdade e liberdade, como em outras democracias, já que tal regime político pressupõe apenas igualdade formal, ou seja,

\footnotetext{
${ }^{28}$ Entre os paradoxos apontados como gerais, importante a observação de Sorj (2004, p. 29) que, sem distinções entre esta ou aquela sociedade, pondera: "Os diversos esforços de criação de modelos societários navegaram, e ainda navegam, entre aqueles que, em nome dos direitos individuais, se recusam a aceitar que o Estado garanta uma maior igualdade e aqueles que, em nome da igualdade, se dispõem a delimitar, ou mesmo eliminar, as liberdades individuais" (SORJ, 2004, p. 29). Touraine (2012, p. 344), nesse mesmo sentido, diz que a "história da democracia [...] é a história da separação progressiva desses dois princípios, da soberania popular e dos direitos do homem. A ideia de soberania popular tendeu a deformar-se numa ideia de um poder popular que faz pouco caso da legalidade e se enche de aspirações revolucionárias, enquanto a defesa dos direitos do homem muitas vezes reduziu-se à defesa da propriedade".
} 
perante a lei, e não material, a despeito de ser esta igualdade, também, um dos ideais contidos nas revoluções do século XVIII. Contudo, a estruturação social - do Brasil Colônia até a contemporaneidade - fez com que vínculos de cidadania sempre tivessem menos peso que relações clientelistas (SALES, 1992). E, assim, a democracia brasileira difere das de muitos países centrais - mesmo levando em conta seus paradoxos gerais e peculiares - que, através da igualdade formal e do Estado de Bem-estar Social, alargaram a percepção de um destino comum, minimizando, assim, o desequilíbrio do metafundamento da cidadania moderna, ou seja, do binômio indivíduo-nação.

Entretanto, além destas características da democracia - sejam as consideradas gerais, sejam aquelas observadas como singulares ao Brasil - a via democrática ainda encontra outros pontos de aproximação com a desigualdade social, como será observado na próxima parte deste estudo.

\section{A DESIGUALDADE SOCIAL E O POPULISMO}

Todorov (2012), ao debruçar-se sobre quais seriam os inimigos da democracia ${ }^{29}$ na contemporaneidade, aponta para o surgimento de um fenômeno interno relacionado a esta forma de governo: $\mathrm{o}$ fortalecimento de partidos de viés populista. Para este autor, tal condição pôde ser percebida, na Europa, sobretudo a partir do fim da Guerra Fria - com a queda do Muro de Berlin -, "como se a vida pública precisasse de um adversário que lhe servisse de contraste, e, após o desaparecimento do rival comunista, a população devesse fixar seus medos, suas inquietações ou outras rejeições em outro grupo qualquer" (TODOROV, 2012, p. 153). Em sua análise - feita dentro do contexto europeu, como já frisado -, este autor projeta os estrangeiros, principalmente os de origem muçulmana, e as elites locais, os ricos, como a encarnação da atual ameaça ideológica, ou seja, como aqueles que, dentro do discurso populista, devem ser vistos como os inimigos ${ }^{30}$.

Contudo, mesmo partindo de uma ideia que remete a uma espécie de continuidade, como se a lacuna aberta pela queda do Muro de Berlin, em 1989, precisasse ser preenchida, ainda, por um grupo que sinalizasse o mal, ocupando, assim, o lugar deixado em aberto pelo antigo inimigo externo, Todorov (2012, p. 156 - colchetes nossos) esclarece que a "ascensão atual [do populismo] mostra que uma grande página da história do século XX finalmente foi virada [de forma que] o novo populismo não é um renascimento dos utopismos de ontem".

\footnotetext{
${ }^{29}$ Para este autor, os inimigos da democracia - como ele denomina as ameaças contemporâneas deste regime político - não são mais externas ao próprio regime, como o comunismo, por exemplo: “[...] não há inimigo global, rival planetário. Em contraposição, a democracia produz, nela mesma, forças que a ameaçam, e a novidade de nossos tempos é que essas forças são superiores àquelas que a atacam por fora" (TODOROV, 2012, p. 14).

${ }^{30}$ Ao propor a ideia de um inimigo, o populismo trabalha, segundo Todorov (2012, p. 161 - grifo do autor; colchetes nossos), com o medo e, portanto, também com a necessidade de combater esse inimigo. Nesse sentido, para este autor, duas são as possibilidades: "Para as forças de extrema esquerda, o inimigo culpado é definido no plano social: são os ricos, os capitalistas, os burgueses; para curar a sociedade, é preciso vencer esses inimigos e fazê-los pagar a conta [... Já] A extrema direita de hoje se define por sua prevenção xenófoba e nacionalista: tudo é culpa dos estrangeiros, daqueles que são diferentes de nós; vamos expulsá-los". vol.08, nº. 03, Rio de Janeiro, 2015.pp. 1211-1243 
Assim, embora acene para uma espécie de sequência - a necessidade de um inimigo ou, ainda, algo ou alguém a se temer -, este autor também projeta, portanto, novos contornos, pontuando uma das principais características deste fenômeno na contemporaneidade como a demagogia, ou seja, a identificação dos interesses do maior número de cidadãos e, a partir disso, o lançamento de propostas - ao mesmo tempo fáceis de assimilar e impossíveis de executar ${ }^{31}$ - para solucioná-las. Diz este autor, em comparação a um democrata ideal ${ }^{32}$, acerca desta característica do populismo:

O modo de apresentação do populismo é a demagogia; quanto ao conteúdo, ele se fixa em torno de algumas constantes. Antes de mais nada, o populista se recusa a afastar-se do aqui e agora, assim como dos indivíduos específicos; foge das abstrações, das distâncias, da duração, e privilegia o concreto, o próximo, ou mesmo o imediato. Enquanto o democrata ideal tenta encontrar sua inspiração no que Rousseau denominava a vontade geral - uma construção hipotética daquilo que, em qualquer momento, seria mais conveniente a todo o povo -, o populista se dirige à multidão com a qual está em contato: aquela de um comício em praça pública, aquela constituída pelos ouvintes de um programa de televisão ou de rádio ${ }^{33}$. O democrata se vê levado a defender valores impopulares, a preconizar sacrifícios, pois também se preocupa com as gerações vindouras; o populista joga com a emoção do momento, forçosamente efêmera. Em nome do interesse geral, o democrata está pronto a intervir em favor das minorias do país; o populista prefere limitar-se às certezas da maioria (TODOROV, 2012, p. 158-159).

Já Wieviorka (1993, p. 93), em complemento a esta síntese do populismo - proposta, inicialmente, a partir da análise de Todorov (2012) - pontua que os representantes de tal fenômeno, buscando aproximar o povo ao poder, atuam de "forma mítica, isto é, procurando conciliar através do seu discurso aquilo que na prática é inconciliável ou difícil de conciliar", concluindo:

Esta representação do populismo pode ajudar-nos a compreender alguns dos seus aspectos. Ao aglutinar de maneira mítica registros altamente contraditórios, o populismo atribui um papel central aos operadores do $\underline{\text { mito, àqueles que asseguram a sua formação, e que se poderão designar por }}$ intelectuais - o que não exclui um eventual anti-intelectualismo, sempre que os próprios intelectuais aparecem ligados ao poder, distantes, ou que possam ser apercebidos como a expressão por excelência da distanciação entre o povo e o poder. O caráter mítico do seu modo de operar leva também a que possa identificar-se com dirigentes carismáticos, personagens capazes de, sem que as contradições dos seus discursos os embaracem, encarnar no

\footnotetext{
${ }^{31}$ Todorov (2012, p. 157 - grifo nosso) dá interessante exemplo, ao projetar a fala ideal de um candidato populista: "Se eu for eleito, darei mais recursos à polícia, construirei novas prisões, pagarei um salário às mães que ficam em casa. Todas elas, medidas que custam caro; no entanto, o mesmo demagogo promete reduzir os impostos".

${ }^{32}$ Dahl (2012), ao avaliar as críticas feitas à democracia, como a dos anarquistas, por exemplo, alerta para a deficiência do método que, segundo ele, compara o ideal - a proposta, utópica e, no plano das ideias, perfeita - com o real - a própria democracia, com todos os seus defeitos e contradiçōes. Embora comunguemos do posicionamento deste autor, entendemos, por seu turno, que a comparação de Todorov (2012), aqui, é válida, pois sinaliza o objetivo a ser perseguido em toda democracia, ao evidenciar as contradições do próprio populismo.

${ }^{33}$ Não por acaso, Todorov (2012, p. 158) refere-se ao rádio e à televisão, deixando de lado outro importante veículo de comunicação social: o jornal impresso. Para este autor, nos veículos citados, a velocidade de transmissão da informação "[...] favorece as frases curtas e claras, as imagens impressionantes e fáceis de reter".
} 
espaço público a síntese da identidade e da mudança, do passado e do futuro, que está no âmago de qualquer impulso populista (WIEVIORKA, 1993, p. 96 - grifo nosso).

Souza (2004, p. 237), por sua vez, sugere que essa tentativa de aproximação de povo e poder - como pondera Wieviorka (1993) - se dá através da idealização de um "Estado forte capaz de integrar os cidadãos à comunidade", de forma ambígua ${ }^{34}$, organizando e tutelando as classes populares no intuito de chegar ao poder e, ainda, mantê-lo ${ }^{35}$.

Desta maneira, é possível, a partir das análises de Todorov (2012), Wieviorka (1993) e Souza (2004), elaborar um conceito, ainda que mínimo, para o populismo: é uma tentativa de abolir as distâncias entre o povo e o poder, através de um discurso demagógico, alinhado ao interesse do maior número de pessoas, fácil de assimilar e, ao mesmo tempo, difícil ou impossível de ser realizado. É ainda composto por um discurso que, embora não possa ser percebido como a continuidade dos medos pré-queda do Muro de Berlin, sinaliza de igual modo para a ideia de um inimigo, um grupo a se temer e combater, sejam os estrangeiros - sobretudo, na Europa, os de origem muçulmana -, sejam as elites. Por fim, como produto da própria demagogia que lhe caracteriza, promove a idealização de um Estado forte - cujos operadores, os líderes executivos, assumem papel central nesse contexto -, que tutela e organiza classes e setores sociais, no intuito de ampliar suas bases de legitimação e, consequentemente, facultar o acesso e a manutenção do poder.

Por meio desta conceituação mínima, portanto, é possível concluir, preliminarmente, que o populismo não é apenas - como propôs Todorov (2012) - um inimigo à democracia, mas, também, um obstáculo para superar a desigualdade. Afinal, tal fenômeno social - o da desigualdade - mostra-se como o produto de uma série de fatores complexos, desenhados a partir da estratificação social moldada inicialmente no Brasil Colônia, atravessando as diversas etapas da História do país e legitimados de acordo com cada período ${ }^{36}$, de modo que soluções fáceis e míticas, características da demagogia e, em decorrência, do populismo, não podem ser projetadas para o enfrentamento da desigualdade social. Além disso, importante não perder de vista que, se a desigualdade pode, como visto anteriormente, ser associada aos limites de alcance da própria cidadania, o protagonismo dos líderes executivos - e consequentemente o desprestígio da atuação legislativa - também implica, por outro lado, em uma espécie de boicote ao combate à desigualdade. Afinal, tal condição tende a favorecer a impressão de que

\footnotetext{
${ }^{34}$ A ambiguidade de que fala Souza (2004), de forma similar à demagogia apontada por Todorov (2012), refere-se, sobretudo, à crítica do capitalismo, típica, segundo este autor, deste regime, mas sem ensaiar possibilidades de rupturas com o próprio capitalismo.

${ }^{35}$ Segundo Sá (1979), a ampliação das bases políticas é o objetivo de todo regime populista. Nesse sentido, parece evidente o fato de que tanto a tutela quanto a própria organização de setores ou classes sociais através do Estado é direcionada a esse intuito.

${ }^{36}$ Referimo-nos, nesse sentido, às heranças de sangue - a partir da colonização -, e ao controle diferencial dos meios de produçãoa partir da modernização do país, constituindo-se, portanto, em um fenômeno complexo e, assim, inconciliável com soluções mágicas e demagógicas.
} 
as mudanças pretendidas dependem de um único indivíduo - o líder -, enfraquecendo a própria democracia e, consequentemente, um projeto voltado a uma sociedade de iguais, assentado no direito.

Desse modo, a questão que se desenha nesta etapa do estudo passa a ser: é possível, no Brasil, encontrar as características do populismo, sucintamente descritas anteriormente e, consequentemente, identificar um entrave além dos já observados no que se refere ao combate à desigualdade social a partir do regime democrático?

Buscando resposta a esta questão, importante destacar, inicialmente, que, conforme observado anteriormente - ao analisar a relação entre democracia e desigualdade social a partir da estruturação da sociedade brasileira -, depreendem-se duas possibilidades que, somadas, ajudam a explicar a coexistência da desigualdade paralelamente à democracia: a primeira, voltada à formação das sociedades modernas como um todo, apontando para a predominância da liberdade sobre a igualdade neste regime político, não obstante a tradição fomentada a partir das Revoluções Liberais (ROSANVALLON, 2012); e a segunda, mais ligada às particularidades brasileiras, convergindo para a fragilidade dos vínculos de cidadania (SALES, 1992; CARVALHO, 2002), de modo que o enfrentamento à desigualdade, historicamente, foi constituído, como já visto, em matéria de assistência - e não de direito $^{37}$-, variável, evidentemente, de governo a governo - e medidas compensatórias, independente da forma política $^{38}$.

Para Carvalho (2002), o sentimento e a impressão popular que decorrem desse encadeamento de fatores favoreceu a idealização de figuras messiânicas, capazes de encarnar o sentimento da mudança cobrada pelo povo (WIEVIORKA, 1993), sem que as ambiguidades do discurso sobressaíssem, favorecendo a prática populista $^{39}$ na política brasileira:

Ligada à preferência pelo Executivo está a busca por um messias político, por um salvador da pátria. Como a experiência de governo democrático tem sido curta e os problemas sociais têm persistido e mesmo se agravado, cresce também a impaciência popular com o funcionamento geralmente mais lento do mecanismo democrático de decisão. Daí a busca de soluções mais rápidas por meio de lideranças carismáticas e messiânicas. Pelo menos três dos cinco presidentes eleitos pelo voto popular após 1945, Getúlio Vargas,

\footnotetext{
${ }^{37}$ Carvalho (2002) observa, por exemplo, que os direitos sociais surgem em períodos de autoritarismo, em que o Legislativo tinha pouca ou nenhuma importância. Ou seja, a assistência pode ser compreendida, nesse sentido, como uma decisão política do Executivo, e não como um direito assegurado através da legislação, colocando, desta maneira, o operador do mito na centralidade (Wieviorka, 1993) de um Estado forte (SOUZA, 2004).

${ }^{38}$ Pensar a questão da desigualdade a partir de medidas compensatórias não é uma característica da democracia, mas também demarca outras formas políticas, como o Estado Novo de Vargas e a Ditadura Militar. Como exemplo, convém ressaltar a LBA Legião Brasileira de Assistência -, criada na década de 1940 como ferramenta para ajudar as famílias dos soldados brasileiros enviados à Segunda Grande Guerra - e cuja atuação foi ampliada a todas as famílias necessitadas após o fim dos conflitos (NEVES, 1994) -, bem como a atuação dos militares, de "caráter compensatório [...e] constituída de políticas assistencialistas que buscavam minorar os impactos das desigualdades crescentes provocadas pela aceleração do desenvolvimento capitalista” (MEDEIROS, 2001, p. 14 - colchetes nossos).

${ }^{39}$ As figuras messiânicas aludidas por Carvalho (2002), além do discurso demagógico que caracterizam o populismo, também são relacionadas à ideia de um inimigo a combater. o capital estrangeiro frente aos trabalhadores, no caso de Vargas, o funcionalismo público, no de Jânio, e os marajás, diante dos descamisados, para Collor.
} 
Jânio Quadros e Fernando Collor, possuíam traços messiânicos. (CARVALHO, 2002, p. 221-222).

Por meio da lição deste autor, é possível não apenas identificar o populismo no Brasil, como se propõe esta parte do estudo, como também observar que, ao passo que se constituiu em um obstáculo ao enfrentamento da desigualdade - diante de suas próprias características, como visto anteriormente -, também se alimentou da própria desigualdade social. Ou seja, embora o populismo seja o produto de uma série de outros fatores, como se verá adiante, a própria desigualdade - ou os problemas sociais agravados, como projeta Carvalho (2002) favoreceu a prática populista no Brasil.

Por isso, de igual modo, a ideia de um messias político - ou a percepção, através do povo, de sua necessidade -, também encontra, para Weffort (2003), forte ligação com as práticas consolidadas na República Velha ${ }^{40}$, cuja atuação dos partidos políticos não implicava, segundo este autor, em representação dos anseios populares, mas, sim, na busca dos interesses das elites no comando do país, apenas acomodando - por meio de concessões - as tensões sociais da população, sem, contudo, enfrentá-las de fato.

Desta maneira, em razão do distanciamento histórico entre população e seus representantes legislativos, o protagonismo político dos chefes do Executivo - aqueles que, em tese, pela boa vontade, e não pelo direito, poderiam melhorar a vida das pessoas - avançou, ganhando, segundo Weffort (2003), novos contornos a partir do crescimento das cidades, diante do Brasil que começava a se modernizar. Afinal, ainda na esteira deste autor, com a formação e com o aumento de centros populacionais já constituídos, os vínculos entre o poder e as bases que legitimavam o próprio poder foram alterados, e seu alcance, sua manutenção e a defesa de determinados interesses já não eram possíveis através dos modelos que vigoraram até 1930 - coronelismo, oligarquias -, em que as relações que garantiam o domínio dos grandes proprietários sobre as bases eram não apenas políticas, mas, também, econômicas e sociais. A população, assim, é finalmente incluída - pelo crescimento das cidades e, consequentemente, pelo peso do voto - na política:

Por força das transformações sociais e econômicas que se associavam ao desenvolvimento do capitalismo industrial e que assumem um ritmo mais intenso a partir de 1930, a democracia defronta-se [...] com a tarefa trágica de toda democracia burguesa: a incorporação das massas populares ao processo político. $\mathrm{O}$ crescimento das cidades e do proletariado lança à vida política amplos contingentes da população, e o processo de absorção das massas passa a constituir uma dimensão política essencial de novo período. [... Por isso,] Vargas, já em 1950, quando se elege presidente diretamente pelo voto popular, tocava no ponto essencial em comentário que teria feito sobre a designação de seu ministério: "Governo popular, ministério

\footnotetext{
40 Embora tal período não reúna as condições necessárias ao populismo, dependente, sobretudo, do crescimento das cidades, é nesse período que o descrédito popular com o Legislativo ganha contornos significativos. Conveniente recordar, nesse sentido, que, conforme Costa (1987), o Partido Republicano manteve um programa de governo vago, sem consultar ou traduzir os anseios da população, inclusive os da burguesia que se formava, em metas políticas. Por isso, Weffort (2003, p. 20) salienta: "Em verdade, o desprestígio do Parlamento, por exemplo, era um fato bastante evidente há muito tempo. Do mesmo modo, era manifesto que a participação eleitoral das massas orientava-se predominantemente para os pleitos executivos".
} 


\section{reacionário; por muito tempo ainda terá que ser assim” (WEFFORT, 2003,} p. 15-16 - colchetes nossos; aspas do autor).

De fato, trata-se de um novo período, como aponta este autor, em que não é mais possível pensar o poder - seja do ponto de vista de quem o almeja, seja sob o prisma de sua manutenção - distanciando-se dos anseios e necessidades da população. Afinal, enquanto nos modelos anteriores as relações de dependência social e econômica eram refletidas no plano político como forma de se atingir a cidadania concedida cunhada por Sales (1992), favorecendo um vínculo estreito e íntimo que permitia a apropriação do público pelo privado através de um cenário local - as localidades do interior sob o domínio de um senhor rural -, o crescimento das cidades fez supor o desaparecimento dessas relações de dependência, tanto social quanto econômica, centrando o vínculo entre base e liderança, frequentemente, apenas nas relações políticas ${ }^{41}$ (WEFFORT, 2003).

Entretanto, esse novo período da política brasileira não se constituiu em uma completa ruptura com o modelo anterior. Embora aponte para significativas diferenças, o novo período manteve a figura do chefe político, que, apoiada no desprestígio do Legislativo, transformou "a relação política numa relação entre indivíduos" ${ }^{\text {"2 }}$ (WEFFORT, 2003. p. 18 - grifo do autor), como se pode depreender da nota editorial da revista Anhembi, de dezembro de 1950, ao assinalar a exaltação de um líder executivo:

"No dia 3 de outubro, no Rio de Janeiro, era meio milhão de miseráveis analfabetos, mendigos famintos e andrajosos, espíritos recalcados e justamente ressentidos, indivíduos que se tornaram pelo abandono homens boçais, maus e vingativos, que desceram os morros embalados pela cantiga da demagogia berrada de janelas e automóveis, para votar na única esperança que lhes restava: naquele que se proclamava o pai dos pobres, o messias-charlatão" (WEFFORT, 2003, p. 21 - aspas do autor).

Assim, em que pese o resentimento contido na nota da revista Anhembi - que provavelmente refletia a insatisfação da parcela da população saudosa "dos tempos austeros da República Velha, quando o suborno e a corrupção eram apenas individuais" (WEFFORT, 2003, p. 21 - grifo do autor) -, o texto demonstra a transformação pela qual passava a política nacional, em "que a democracia brasileira veio progressivamente deixando de ser mera formalidade, como o fora antes de 1930, quando apenas consagrava os ajustes de interesses dos grupos dominantes" (WEFFORT, 2003, p. 21). A partir de então, assinala este autor, não é mais possível ascender ao poder - e manter-se nele -, desvinculando-se das expectativas populares frente à "emergência política das massas" (WEFFORT, 2003, p. 16).

Contudo, alinhavando a conceituação inicial de populismo à análise de Neves (1994), percebe-se que o atendimento das expectativas populares, a partir do período assinalado por Weffort (2003), não ocorreu através

\footnotetext{
${ }^{41}$ Conforme Souza (2004, p. 245), o populismo, mesmo reconhecendo novos atores políticos - o povo, de maneira geral -, e apresentando características e contextos que o difere do coronelismo, mantém semelhanças com o antigo modelo, já que ambas "geram formas de manipulação de interesses e desejos".

${ }^{42}$ Nesta relação entre indivíduos, como propõe Weffort (2003), o líder populista, ao atender as demandas reclamadas, reivindica reciprocidade diante da generosidade estatal(SOUZA, 2004).
} 
da afirmação dos indivíduos como cidadãos de direitos, mas, sim, como o produto da boa vontade e da caridade, do discurso mágico e demagógico, de modo que, para esta pesquisadora, o atendimento das expectativas populares não passou:

De um simulacro no enfrentamento da pobreza, longe da perspectiva redistributiva, da equidade e da universalização aos cidadãos. A assistência origina-se na mistificação da tutela e do controle da pobreza. A mágica encontrada pelo Estado no governo Vargas [a partir de 1930] torna-se uma ação perversa, que coloca o cidadão como carente, onde a assistência é a lógica encontrada como saída e resposta do Estado num contexto históricosocial bastante conturbado na sociedade (NEVES, 1994, p. 31-32 colchetes nossos).

Tal descrição, que muito bem pode ser alinhada ao conceito de populismo formado a partir das lições de Todorov (2012), Wieviorka (1993) e Souza (2004), não ficou, para Neves (1994, p. 28), restrita à Era Vargas, e essa maneira de atender às expectativas das massas, alicerçada na reprodução de um discurso ideológico dominante, "tendo como finalidade dar homogeneidade e identidade à sociedade, mascarando-se a divisão da sociedade em classes e com interesses antagônicos" ${ }^{43}$, foi pouco alterada nas décadas posteriores ${ }^{44}$. E, em que pese o fato de as questões sociais tornarem-se prioritárias a partir da redemocratização do país, como assinala ainda esta pesquisadora, essa prática, ou essa espécie de benevolência estatal voltada ao aumento das bases de sustentação do poder (SÁ, 1979), chegou à contemporaneidade brasileira. Afinal, ainda hoje, a “[...] a ideologia do favor aparece no imaginário social em virtude da tradição clientelista e populista presente na formação da sociedade brasileira" ${ }^{45}$ (NEVES, 1994, p. 75).

Importante destacar, entretanto, que não é a simples ideia de favor ou benevolência - frente ao direito que faz supor a permanência do populismo na contemporaneidade brasileira, mas o fato de tal prática - espécie de continuidade do coronelismo adaptado ao crescimento das cidades a partir dos Anos 1930 - favorecer a manutenção do líder executivo na centralidade do cenário político, proporcionando o surgimento de figuras carismáticas que, através de discursos demagógicos, de falsa inclusão, buscam a ampliação de suas bases - bases estas conquistadas pela ideia de favor -, projetando o acesso e a manutenção do poder.

\footnotetext{
${ }^{43}$ Bom exemplo do mascaramento do antagonismo de classes apontado por Neves (1994) pode ser apreendido a partir da observação de Sá (1979, p. 37 - parênteses e aspas do autor; grifo nosso). Segundo este autor, os novos grupos no poder, a partir de Vargas, "representando, basicamente interesses dos empresariados, são forçados, de início, para o próprio sucesso da revolução de 1930, a aliar-se às oligarquias insatisfeitas no sistema anterior. Para seu próprio fortalecimento, impunha ampliar suas bases políticas no seio da massa urbana. E, para não comprometer o sistema básico de acumulação, admitiram logo a seguir os principais grupos agro-exportadores no sistema de poder. O resultado foi a formação da 'aliança desenvolvimentista', como comumente é conhecida, composta por setores 'tradicionais' do latifúndio, massas urbanas (operariado, artesãos, camadas médias), empresariado (industriais, financistas e comerciantes), e, finalmente, os principais elementos do setor agro-exportador".

${ }^{44}$ Neves (1994, p. 32) faz referência aos Anos 1950 e 1960, apontando para uma espécie de continuísmo. Contudo, salienta esta pesquisadora que a principal característica do período foi encarar a desigualdade social "a partir dos planos econômicos, que tinham como objetivo o desenvolvimento nacional do país”. Além disso, esta pesquisadora pontua que, nos Anos 1970 e 1980, com os governos militares e a ideia de milagre econômico que caracteriza o período, o combate à pobreza passa a ser visto como estratégico para o crescimento econômico do país, e não sob o enfoque da cidadania.

${ }^{45}$ A ideia de favor - ou ajuda - é dominante entre as pessoas assistidas pelo Estado (NEVES, 1994; YASBEK, 2009). vol.08, nº. 03, Rio de Janeiro, 2015.pp. 1211-1243 
Além disso, importante destacar que, se Vargas exerceu "sobre as classes trabalhadoras uma função de organização e tutela" (SOUZA, 2004, p. 239), buscando, sobretudo, bases sólidas e reconhecimento, mas, também, impondo limites à autonomia dos trabalhadores frente ao Estado, a ideia de favor frente ao direito, atualmente, não cria apenas uma clientela ${ }^{46}$, da qual, do mesmo modo, se espera reconhecimento, mas promove, igualmente, mecanismos de controle. Afinal, como projeta Yasbek (2009, p. 162 - grifo nosso; aspas da autora):

As instituições que atuam na área apresentam-se como benevolentes, assistenciais, promocionais ou de bem-estar social, colocando um conjunto de requisitos e exigências para a obtenção do benefício ou ajuda que oferecem. Muitas vezes exigem "disciplinamento, obediência aos rituais, resignação e conformismo" às suas determinações. A "clientela" deve ser "orientada e assistida [...] A imagem ideal da clientela para a instituição é ser cordata, conformada, submissa".

Frente à persistência destas características do populismo na atualidade, Marques e Mendes (2006, p. 70) referem-se a uma espécie de "novo populismo" no Brasil. Segundo estes autores, embora o fenômeno reúna muitas semelhanças com a prática no passado, como a crença de que o "desenvolvimento econômico e a distribuição de renda podem ser realizados facilmente", acenando, portanto, para um discurso mítico e demagógico, típico do populismo, e buscando, através dos assistidos, reconhecimento, controle e, consequentemente, a ampliação das bases através das massas incluídas na democracia - como projetou Weffort (2003) ao analisar o surgimento do fenômeno a partir dos Anos 1930 -, tal prática na contemporaneidade brasileira diferencia-se da do passado pela forma de cooptação das bases. Para estes autores, enquanto o populismo que emerge com Vargas assentou as bases em classes - e, por isso, Weffort (2003) afirma que, ao se falar nesta expressão política, não é possível referir-se a massas, mas a classes -, a prática que se inaugura com o Governo Lula buscou um novo tipo de base, mais ampla, projetando, assim, um novo populismo:

O governo Lula, através da implementação de programas de transferência de renda, começa a lançar as bases de um novo tipo de apoio, agora assentado no segmento de mais baixa renda do país. A relação que estabelece com esse segmento constitui as bases de um "novo populismo" (MARQUES E MENDES, 2006, p. 59 - aspas dos autores).

Assim, embora Marques e Mendes (2006) apontem para ambiguidades típicas do populismo no Governo Lula, como a crítica ao capital, mas sem ações que, de fato, produzissem uma ruptura ${ }^{47}$, ou para o fato de que, neste governo, a relação próxima entre o próprio governo e o sindicalismo foi utilizada, tal como com Vargas,

\footnotetext{
${ }^{46}$ A ideia de clientela remete, evidentemente, à manipulação. Contudo, Souza (2004, p. 239 - aspas do autor) adverte que "a ideia de manipulação deve [...] ser vista com ressalvas. A população a ser "manipulada" tem interesses concretos a serem atendidos e só concorda com o compromisso que fundamenta seu vínculo com os líderes populistas na medida em que percebe a existência de ganhos reais". Contudo, se a prática populista é demagógica, como pontua Todorov (2012), a atenção aos interesses populares pode significar tão somente uma saída mágica e imediatista para um problema complexo, apelando à falácia de que ninguém sabe, mais que a própria pessoa, o que é melhor para si (SOUZA, 2009).

${ }^{47}$ Marques e Mendes (2006) referem-se, nesse sentido, ao fato de que o Governo Lula assumiu tanto as agendas do FMI quanto do Banco Mundial, com, em tese, interesses antagônicos à classe dos trabalhadores. Importante não perder de vista que, como vimos através da lição de Souza (2004), a crítica ao capital, mas sem ações que levem, de fato, a uma ruptura, é uma característica típica do populismo.
} 
como instrumento de controle ${ }^{48}$ - acenando, até aqui, para a continuidade da prática -, o que inaugura uma espécie de novo formato populista, para esses autores, é não mais buscar a ampliação das bases através de uma classe específica ${ }^{49}$, mas, sim, através das massas - ou a maior classe de todas, a dos pobres -, com programas de transferência de renda.

Evidentemente, os programas de transferências de renda, sobretudo o Bolsa Família, que reúne uma série de medidas compensatórias, como o Bolsa Escola, o Bolsa Alimentação, o Cartão Alimentação e o Auxílio Gás, dirigidos a famílias pobres ou extremamente pobres, em si, não podem ser considerados populistas. Afinal, em um país capaz de apresentar índices tão alarmantes de disparidade social, historicamente consolidados, como o Brasil, tais programas mostram-se como uma ferramenta que permite ao Estado resgatar:

Parte de uma dívida social com uma parcela imensa de sua população [...] ajudando o Brasil a iniciar a superação de seu grande desafio do século XXI: tornar-se um país que seja, além de uma das grandes potências econômicas, mais justo, garantindo as condições mínimas necessárias para uma vida com mais dignidade (BEDIN E SANTOS, 2012, p. 400-401).

Por isso:

Não há dúvida de que os programas compensatórios, dos quais destacamos o Bolsa Família, mas que a ele deveriam ser somados os implementados pelos governos estaduais e municipais (induzidos pela política federal) constituem um esforço sem paralelo, de transferência de renda para as famílias mais pobres, na história do país. Os programas sociais realizados pelos governos militares mediante a Legião Brasileira de Assistência (LBA) e mesmo os iniciados durante a presidência de Fernando Henrique Cardoso não se comparam em valor e quantidade de beneficiários (MARQUES E MENDES, 2006, p. 69 - parênteses do autor).

De fato, trata-se de um esforço sem paralelo ${ }^{50}$, como ponderam esses autores. Contudo, embora sejam importantes ferramentas para minimizar os efeitos da pobreza de cerca de 14 milhões de famílias brasileiras (IBGE, 2013), tais programas de transferência de renda - que não são acompanhados de atividades de capacitação e emancipação ${ }^{51}$ - criam importantes vínculos diretos entre o líder executivo e as massas beneficiadas,

\footnotetext{
48 “Essa relação estreita entre governo, partido e sindicato, explica, em parte, porque foi tão fácil para o governo aprovar a reforma da previdência, não valorizar o salário mínimo e promover o aumento do desemprego em seu primeiro ano. As massas, mesmo descontentes, não tinham como se expressar: suas formas tradicionais de organização estavam, pela mão de suas direções, a serviço do governo" (MARQUES E MENDES, 2006, p. 64).

49 Classes especificas como, por exemplo, através do discurso xenofóbico europeu, certamente voltado a um público singular, ou a própria relação de Vargas com os trabalhadores.

${ }^{50}$ Marques e Mendes (2006, p. 69 - colchetes nossos; parênteses do autor) dão um exemplo desse esforço sem paralelo: "Em Pedra Branca [no Estado do Ceará], as transferências do programa (4.088 famílias) totalizam valor correspondente a $43 \%$ da Receita Disponível e são 13\% superiores aos recursos federais SUS e 212\% do ICMS".

${ }^{51}$ Conforme Bedin e Santos (2012), esses seriam elementos necessários para que os programas de transferência de renda fossem, de fato, transitórios, característica que, em tese, deveria integrar as políticas públicas. Contudo, como os mecanismos de le gitimação da desigualdade na contemporaneidade permanecem inalterados, tais programas passam a figurar como necessariamente permanentes, no intuito de impedir o aumento das disparidades sociais, em que pese a implantação, por este mesmo governo, dos programas Fundeb (Fundo de Manutenção e Desenvolvimento da Educação Básica e Valorização dos Profissionais da Educação), ProUni (Programa Universidade para Todos) e Reuni (Programa de Apoio a Planos de Reestruturação e Expansão das Universidades Federal).
} 
acenando, ainda, para uma espécie de desprestígio do Legislativo - herança consolidada na Primeira República e legada ao Brasil que se moderniza a partir de 1930 - ao não se constituir em:

Um direito e sim uma benesse governamental, que pode ser alterada sem grandes discussões a depender do gosto e do interesse do presidente de plantão. Em outras palavras, o combate à pobreza continua a ser tratado como uma atividade meramente assistencial, o que pode resultar no florescimento de todo tipo de clientelismo. [...] os beneficiários dos programas compensatórios, que nunca foram objeto de atenção continuada de qualquer governo, passam a ser a base de apoio inconteste do governo Lula. Vale lembrar que esse segmento da população brasileira apresenta, em geral, baixo nível de organização, estabelecendo assim uma relação direta, sem mediação, com o presidente Lula (MARQUES E MENDES, 2006, p. $70)$.

Através do que foi observado até o momento, portanto, é possível identificar as características do populismo - minimamente elencadas anteriormente - não apenas no passado recente da História do Brasil, a partir de 1930, mas, também, no presente ${ }^{52}$. Contudo, em que pesem as práticas adotadas a partir do crescimento mais acentuado das cidades - fenômeno decisivo para o surgimento do populismo -, ou as características que delimitam o que Marques e Mendes (2006) classificam como novo populismo, importante observar que, embora seja imperiosa a presença de um líder carismático, na centralidade do palco político, com um discurso mágico e demagógico para a caracterização de um regime populista, os elementos que facultam tal deformação do ideal democrático, como visto até aqui, estão enraizados no passado, mal resolvidos no presente e intimamente ligados à própria desigualdade social. Afinal, o líder populista depende, para surgir, justamente de desequilíbrios sociais colocando-se em seguida, diante de um Legislativo sem prestígio, como o único capaz de saná-los.

Por outro lado, um Legislativo considerado ineficiente - seja pelas próprias contradições atuais, seja pelos contornos adquiridos ainda na Primeira República - não pode ser, consequentemente, depositário das expectativas populares, de modo que a mudança projetada recai, nesse contexto, necessariamente no líder executivo. Forma-se, assim, uma espécie de círculo vicioso, em que a esperança de mudança ${ }^{53}$ passa a ser encarnada por aqueles que se dispõem, através do discurso mágico, a promovê-la.

Assim, se a palidez da cidadania no Brasil decorre da "incapacidade do sistema representativo de produzir resultados que impliquem a redução da desigualdade e o fim da divisão de brasileiros em castas separadas por educação, pela renda e pela cor" (CARVALHO, 2002, p. 229) - e o populismo alimenta-se, antes, desse contexto - mais importante que o protagonismo do líder carismático, capaz do discurso mágico que esconde suas próprias

\footnotetext{
${ }^{52}$ Importante observar que as ambiguidades e as tentativas de ampliação de bases contidas nos dois governos Lula também faz parte do ideário de sua sucessora, Dilma Rousseff, bem como parecem estar alinhadas à agenda de outros atores políticos, inclusive oposicionistas, que tendem a projetar - na tentativa de aumento das bases - soluções míticas, sempre velozes e fáceis de verificar, em suas plataformas eleitorais. Em outras palavras, através do discurso político, tudo é simples e de fácil solução, bastando, para isso, somente boa vontade.

${ }^{53}$ Como bem exemplificava o editorial da Revista Anhembi, de dezembro de 1950, destacando Vargas como o "messias charlatão", como a "única esperança" que restava à massa de miseráveis que habitava o Rio de Janeiro já na metade do século XX (WEFFORT, 2003, p. 21).
} 
ambiguidades - é um Estado moldado justamente a partir de heranças sociais, voltado, como diz Holanda (1977), ao culto à personalidade, com instituições fracas e, acima de tudo, despido de uma sociedade civil impessoal. Em outras palavras, o populismo - de Vargas à contemporaneidade - ao alimentar-se e ser alimentado pela desigualdade, foi - e ainda é - possível somente a partir das contradições delimitadas no passado brasileiro. Afinal, foram estas que, associadas ao crescimento das cidades, possibilitaram o palco ideal para o surgimento de um entrave moderno - o populismo - ao combate à desigualdade social, justamente dentro da própria democracia, modelo voltado à construção de uma sociedade de iguais.

\section{AS ALTERNATIVAS POSSIVEIS: EM BUSCA DE UMA SOCIEDADE DE IGUAIS}

Conforme Bragato (2013, p. 77), a "ideia de igualdade não é uma preocupação recente no Direito. Esteve, desde a construção da democracia grega, no centro das discussões sobre justiça entendida como expressão da igualdade”. Contudo, segundo esta mesma autora, se, por um lado, a associação de justiça e igualdade já era um ideal a ser alcançado para os antigos, por outro é recente "a concepção liberal de igualdade, concebida para combater os privilégios por motivo de origem de nascimento que sustentavam o absolutismo político da primeira modernidade europeia" (BRAGATO, 2013, p. 78).

A relação temporal entre concepções de igualdade, elaborada por esta autora, evidencia, por seu turno, o caráter histórico dos direitos ${ }^{54}$, ao demonstrar - ainda que não fosse essa a intenção - a fragilidade de uma posição jusnaturalista. Afinal, como se pode depreender deste exemplo, para os antigos a igualdade não significava pôr fim a privilégios. Já para os modernos, sim, de modo que os contextos de cada tempo - é possível afirmar - criam novas necessidades ou as evidenciam, alterando, de certa forma, o conceito de justiça. Por isso, pondera Bobbio (2004, p. 29 - grifo e parênteses do autor):

Os homens, de fato, não nascem nem livres nem iguais. São livres e iguais com relação a um nascimento ou natureza ideais, que era precisamente a que tinham em mente os jusnaturalistas quando falavam em estado de natureza. A liberdade e a igualdade não são um dado de fato, mas um ideal a perseguir; não são uma existência, mas um valor; não são um ser, mas um dever ser. Enquanto teorias filosóficas, as primeiras afirmações dos direitos do homem são pura e simplesmente a expressão de um pensamento individual: são universais em relação ao conteúdo, na medida em que se dirigem a um homem racional fora do espaço e do tempo, mas são extremamente limitadas em relação a sua eficácia, na medida em que são (na melhor das hipóteses) propostas para um futuro legislador.

Neste caminho histórico dos direitos, é possível, portanto, observar que, especialmente no que toca à igualdade - e em que pesem outros direitos humanos também - uma primeira etapa parece vencida: a

\footnotetext{
${ }^{54}$ Referindo-se aos chamados direitos do homem, Bobbio (2004, p. 31-32) observa que estes "[...] são históricos, que emergem gradualmente das lutas que o homem trava por sua própria emancipação e das transformações das condições de vida que essas lutas produzem", afirmando: "[...] os direitos ditos humanos são o produto não da natureza, mas da civilização humana; enquanto direitos históricos, eles são mutáveis, ou seja, suscetíveis de transformação e de ampliação”.
} vol.08, nº. 03, Rio de Janeiro, 2015.pp. 1211-1243 
fundamentação que, segundo Bobbio (2004, p. 28), "deve ser buscada na obra dos filósofos". O momento seguinte à fundamentação, qual seja, a positivação, também. Afinal, os Direitos Humanos estão reconhecidos não apenas em cartas internacionais, como a Declaração Universal dos Direitos Humanos (ONU, 1948), mas também na legislação nacional, em destaque a Constituição Federal (BRASIL, 1988), em seu Artigo 5.

Assim, pondera Bobbio (2004, p. 23 - grifo nosso), que:

Com efeito, o problema que temos diante de nós não é filosófico, mas jurídico e, num sentido mais amplo, político. Não se trata de saber quais e quantos são esses direitos, qual é a sua natureza e seu fundamento, se são direitos naturais ou históricos, absolutos ou relativos, mas, sim qual $\underline{\text { é }}$ modo mais seguro para garanti-los, para impedir que, apesar das solenes declaraçōes, eles sejam continuamente violados.

No que se refere à desigualdade no Brasil, a afirmação deste autor faz um enorme sentido. Afinal, se as etapas anteriores - fundamentação e positivação - fossem garantia suficiente à eficácia dos direitos, não seria preciso projetar alternativas possíveis em busca de uma sociedade de iguais. Ou seja, não se trata, aqui, de justificar - ou fundamentar - por quais motivos os seres humanos devem ser tratados como iguais, mas, sim, observar que causas iniciais impedem a efetivação dos direitos, bem como o modo, portanto, viável para superá-las.

Em relação aos obstáculos para a efetivação dos direitos - em específico os fundamentais -, Bobbio (2004, p. 41) aponta para os próprios conteúdos destes mesmos direitos, segundo ele, concorrentes, em muitos casos, com os de outros direitos. Para este autor, tal constatação decorre do fato de que "não se pode instituir um direito em favor de uma categoria de pessoas sem suprimir um direito de outra categoria de pessoas", de modo que:

Pode-se fantasiar sobre uma sociedade ao mesmo tempo livre e justa, na qual são global e simultaneamente realizados os direitos de liberdade e os direitos sociais; as sociedades reais, que temos diante de nós, são mais livres na medida em que menos justas e mais justas na medida em que menos livres (BOBBIO, 2004, p. 42 - grifo nosso).

$\mathrm{O}$ viés proposto por este autor, portanto, ensaia uma justificativa ${ }^{55}$ para os paradoxos das sociedades democráticas modernas, fundadas na igualdade, mas, em maior ou menor grau, desiguais. E, em que pese o fato da questão ainda se constituir como um problema jurídico, seu foco, deslocado para além da própria ordem jurídica, acaba convergindo para o campo social. Afinal, se a afirmação de um direito implica a negação no mesmo grau de outro, a própria supressão de um direito também tende a anular o primeiro, já que, por exemplo, a pobreza, ou seja, um dos extremos em um contexto de desigualdade - e, portanto um problema antes social do que jurídico -, implica, também, em privação da liberdade:

A ausência de liberdades substantivas relaciona-se com a pobreza econômica, que rouba das pessoas a liberdade de saciar a fome, de obter uma nutrição satisfatória ou remédios para doenças tratáveis, a

\footnotetext{
${ }^{55}$ Referimo-nos a uma justificativa não no sentido de legitimação, mas como causa ou efeito.
} vol.08, nº. 03, Rio de Janeiro, 2015.pp. 1211-1243 
oportunidade de vestir-se ou morar de modo apropriado (SEN, 2010, p. 17).

O que Sen (2010) aponta na prática pode, por seu turno, ser observado, de igual modo, na teoria. Assim, conforme Bielefeldt (2000, p. 114 - grifo nosso), não é possível - ao se buscar a eficácia dos Direitos Humanos admitir:

\begin{abstract}
A possibilidade de se considerar a relação liberdade-igualdade como uma compensação entre uma liberdade antiigualitária e uma igualdade antiliberal. Uma liberdade antiigualitária nada mais seria que um privilégio e, consequentemente, o contrário de um direito humano inato. Por outro lado, uma igualdade antiliberal teria tendência uniformista e repressiva e entraria, também, em contradição aos direitos humanos. [...] liberdade e igualdade estão de tal forma unidas que elas se explicam reciprocamente: somente faz sentido um conceito de liberdade que por princípio busque também a noção de direito humano embutida na igualdade que contém, por princípio, a máxima liberdade para todos. Portanto, em sentido estrito, a relação entre liberdade e igualdade não é a soma desta mais aquela - no que o mais representaria a necessidade de um acordo de equilibrio entre ambas - mas, $\underline{\text { sim, de liberdade como igualdade, ou, ainda, de igualdade na liberdade. }}$
\end{abstract}

A questão, assim posta, parece conter uma contradição dentro de outra: por um lado, não é possível facultar um direito sem suprimir, ao menos em parte, outro direito, conforme Bobbio (2004). Por outro lado, ao se suprimir um direito diante da afirmação de um segundo, projeta-se, contraditoriamente, a negação daquele que foi afirmado (BIELEFELDT, 2000). De outra forma, é possível dizer, então, que, ao se privilegiar a liberdade, por exemplo, não se suprime apenas a igualdade, em alguma medida, mas, sim, se limita a própria liberdade, na mesma proporção. Do mesmo modo, favorecer a igualdade - e, consequentemente, limitar a liberdade - implica, por sua vez, em também negar - ou ao menos limitar - a igualdade. Como, então, afirmar igualdade e liberdade, sem anulá-las?

Bielefeldt (2000) - que, como visto, descarta a hipótese de equilibrá-las - ensaia uma resposta através de um ethos mínimo, ou seja, um ponto de partida comum a todos que, pelo seu conteúdo, não implique em concessões, em limites, possibilitando, assim, um agir livre e, ao mesmo tempo, com igualdade. Já Bobbio ${ }^{56}$ (2004, p. 210 - grifo do autor), por sua vez, adverte que um ethos, como propõe Bielefeldt (2000), pertence a um mundo ideal, afirmando que, "naturalmente, é necessário não esquecer que um ethos representa o mundo do dever ser. O mundo real nos oferece, infelizmente, um espetáculo muito diferente" ${ }^{\text {57 }}$.

As duas considerações, entretanto, não são, necessariamente, excludentes. Afinal, ao passo que um ethos, na perspectiva de Bielefeldt (2000), indica o caminho para que os direitos sejam de fato efetivos, a advertência de Bobbio (2004, p. 210) aponta, apenas, para uma característica do próprio direito, situado nos "tempos longos". Ou

\footnotetext{
${ }^{56}$ Bobbio (2004, p. 2010 - grifo do autor), ao citar o discurso do bispo de Roltenburg-Stuttgart, Walter Kasper, em 1988, intitulado Le fondement théologique des droits de l'homme, concorda: "Os direitos do homem constituem nos dias de hoje um novo ethos mundial".

${ }^{57}$ Evidentemente, não sem razão. Afinal, de acordo com Sen (2010), não apenas muitas liberdades elementares são negadas a um grande número de pessoas, como muitos indivíduos, igualmente, perecem sob uma série de necessidades econômicas.
} vol.08, nº. 03, Rio de Janeiro, 2015. pp. 1211-1243 
seja, enquanto produtos históricos, os direitos percorreram - e, evidentemente, ainda percorrem - um longo caminho. E o ethos é, nada mais, o que norteia esse caminho. Por isso, vem do próprio Bobbio (2004, p. 44) a afirmação de que o respeito aos Direitos Humanos, antes de ser um problema filosófico, moral ou jurídico é, antes, um problema cuja solução depende de “[...] um certo grau de desenvolvimento social”.

Assim, projetar alternativas possíveis, em busca de uma sociedade de iguais - como se propõe a última parte deste estudo -, implica, justamente, em identificar um ethos, ou seja, um mínimo que nos permita avançar na tentativa de construção de uma sociedade mais justa. Em outras palavras, identificadas e superadas as dicotomias que impedem a eficácia do direito, resta compreender, a partir das causas da desigualdade, que tipo de solução deve ser projetado para viabilizar a eficácia do direito. Ou seja, a partir da determinação sobre de que forma de desigualdade se trata, compreender que tipo de demanda é cobrado para tornar pleno o direito à igualdade.

Deste modo, importante destacar quais os mecanismos, na lógica de legitimação da desigualdade social no Brasil, foram determinantes tanto para o surgimento quanto para a manutenção deste fenômeno no país. Neste sentido, evidenciam-se duas possibilidades, distintas entre si, mas entrelaçadas historicamente: a primeira, assentada nas heranças de sangue, coletivizando a desigualdade e formando-a a partir de grupos ${ }^{58}$ senhores/escravos e brancos/negros, por exemplo; a segunda, assentada na apropriação diferencial dos modernos meios de produção, individualizando tal fenômeno, não mais formado a partir de um dado pronto, em tese, natural, mas, sim, determinado pelas aptidões e singularidades de cada indivíduo (SOUZA, 2009). Por isso, buscar soluções viáveis a esse problema - cuja gênese se confunde com a própria formação do país enquanto Estado -, implica em perceber tal fenômeno social não somente como um dado decorrente da estratificação da sociedade brasileira, condição delimitada, neste estudo, a partir do Brasil Colônia, mas, de igual modo, também não percebê-lo apenas como produto de uma apropriação diferenciada de capital cultural como ferramenta para a obtenção diferencial de capital econômico e vice-versa.

Afinal, embora distintos, ambos os mecanismos se entrelaçam historicamente, de modo que, se é a lógica do período colonial ${ }^{59}$ que faz chegar, ao Brasil que se moderniza a partir dos Anos 1930, imensos contingentes populacionais em abissais níveis de desigualdade, tal condição é mantida, por sua vez, somente a partir da modificação dos mecanismos de legitimação desta mesma disparidade, sob o véu de uma pretensa igualdade de condições ${ }^{60}$.

\footnotetext{
${ }^{58}$ Como se pode depreender da leitura de clássicos, como Holanda (1977), Bomfim (2005), Furtado (1959), Faoro (2012) e Ribeiro (2006), por exemplo, bem como de autores contemporâneos, como Sales (1992) e Carvalho (1987; 2002), entre outros.

${ }^{59}$ Lógica cujas heranças de sangue, espécie de ponto de partida para a estratificação social no Brasil, formaram uma espécie de mecanismo de legitimação da desigualdade, perpassando não apenas essa fase da História do Brasil, mas favorecendo a manutenção deste statustanto no Império quanto na Primeira República (BOMFIM, 2005; CARVALHO, 2002).

${ }^{60}$ Igualdade de condições que legitima a desigualdade a partir de uma pretensão teórica sem correspondência com a realidade. Nesta espécie de lacuna entre o dever sere o ser, o mérito pessoal passa a determinar posições e privilégios, anteriormente definidos pelas heranças de sangue (SOUZA, 2009).
} 
Por isso, a busca de soluções possíveis ao problema da desigualdade social, no Brasil, não pode ocorrer apenas sob o enfoque do passado - como uma questão exclusivamente de reconhecimento ${ }^{61}$-, nem apenas através das lentes do presente - como um problema cujo cerne é apenas de redistribuição ${ }^{62}$-, mas, sim, como uma questão que, por ter causas ambivalentes, impõe, necessariamente, propostas ambivalentes, voltando-se tanto ao reconhecimento quando à redistribuição. Afinal, como pondera Fraser (2006, p. 231 - parênteses da autora):

A justiça hoje exige tanto redistribuição como reconhecimento. [...] Isso significa, em parte, pensar em como conceituar reconhecimento cultural e igualdade social de forma que sustentem um ao outro, ao invés de se aniquilarem (pois há muitas concepções concorrentes de ambos!). Significa também teorizar a respeito dos meios pelos quais a privação econômica e o desrespeito cultural se entrelaçam e se sustentam simultaneamente.

De fato, a construção de uma sociedade de iguais demanda, no Brasil, soluções voltadas tanto ao reconhecimento quanto à redistribuição, já que os mecanismos modernos de legitimação da desigualdade social, como vimos, estão assentados, de forma opaca, na obtenção diferencial de capital cultural, e esta é, evidentemente, uma questão de redistribuição, mas, também, de reconhecimento. Afinal, o Estado, ao permitir a produção do mesmo bem - capital cultural - de maneira diferenciada ${ }^{63}$, admite - reconhece, ainda que silenciosamente - o privilégio de uns diante de outros, mantendo a riqueza inicial determinante para a inserção em um mercado de trabalho cada vez mais restrito à incorporação de mão de obra qualificada (POCHMANN, 1998).

Por isso, não basta a redistribuição do ponto de vista econômico, através de programas de transferência de renda - inócuos, diante de outras disparidades - sem reconhecer que o conhecimento, hoje, é o próprio meio de produção. Permitir formas de apropriação diferenciadas, portanto, significa não apenas impedir o acesso ao

\footnotetext{
${ }^{61}$ A associação do reconhecimento ao passado brasileiro decorre do fato de que, em uma sociedade baseada no modelo escravocrata, como foi a nossa até 1888 , inegavelmente se parte do princípio de que há diferenças entre os indivíduos, ou seja, não há o reconhecimento destes como iguais.

${ }^{62} \mathrm{~A}$ associação da redistribuição ao presente decorre do fato de que, hoje, embora todos sejam reconhecidos formalmente como iguais, uma série de serviços, como educação, por exemplo, é acessada de maneira diferenciada. Destacamos este direito social, em que pesem outros, como saúde, por exemplo, por ser justamente a educação o espaço da luta contemporânea de classes no Brasil (FERREIRA, 2000), facultando, através do acesso diferencial entre ricos e pobres, o mérito de saber o que é preciso para encaixarse no mercado, determinando, portanto, privilégios.

${ }^{63}$ Segundo o Ministério da Educação (MEC, 2014), observados os números que medem a qualidade de cada escola e de cada rede de ensino com base no desempenho do estudante em avaliações do Inep - Instituto Nacional de Estudos e Pesquisas Educacionais - e em taxas de aprovação, a rede pública fica atrás da rede privada de ensino em todos os níveis de educação ofertados. E o pior, nem mesmo as metas previstas para 2021, último ano com índice projetado, vislumbram diminuição significativa - quando vislumbram - no abismo que há entre o público e o privado. Enquanto o Ensino Fundamental - Anos Iniciais - apresentou índice de 4,9 pontos para a rede pública em 2013, último ano analisado, a rede privada somou 6,7 pontos. A diferença é de 1,8 ponto. Para 2021, a meta para o ensino público é de 5,8 pontos, ou seja, ainda inferior à rede privada hoje, cuja meta para o mesmo período é de 7,5 pontos. Se ambas as dependências administrativas atingirem suas respectivas metas, a defasagem será de 1,7 , apenas 0,1 ponto abaixo da atual diferença. Nos Anos Finais do Ensino Fundamental, a diferença é ainda maior. Enquanto as escolas públicas, entre estaduais e municipais, alcançaram 4,0 pontos, a rede privada de ensino chegou a 5,9 pontos. A diferença entre uma dependência administrativa e outra é de 1,9 ponto. Se ambos os sistemas atingirem suas metas para 2021 (5,2 para a rede pública e 7,3 para a rede privada), a diferença será ampliada para 2,1 pontos. Por fim, no Ensino Médio, as escolas públicas produziram, em 2013, um Ideb de 3,4 pontos, enquanto as privadas, 5,4 pontos. A atual diferença é de 2,0 pontos, a maior diferença entre todos os níveis de ensino analisados pelo Inep. Em 2021, se as duas dependências administrativas alcançarem suas metas (4,9 para a rede pública e 7,0 para a rede privada), a diferença será, em uma década de avaliação, de 2,1 pontos, ou seja, superior à atual diferença.
} vol.08, nº. 03, Rio de Janeiro, 2015. pp. 1211-1243 
instrumento que, em tese, garante a reprodução da vida social, mas, acima disso, não reconhecer todos como iguais. Esse reconhecimento - que na prática cobra redistribuição - é o ethos mínimo projetado por Bielefeldt (2000), capaz de nortear a busca por uma sociedade de iguais.

Contudo, a construção deste ethos, desenhado a partir de traços voltados tanto ao reconhecimento quanto à redistribuição, por si, não basta. Afinal, ele é - como visto através da lição de Bobbio (2004) - apenas um ideal a ser alcançado, ou seja, indica uma trajetória no caminho a percorrer, mas não é o próprio caminho. Este, por sua vez, depende da "[...] criação de instituições que transformem o Estado em parte da sociedade e esta em parte do Estado, gerando um espaço representativo do bem comum" (SORJ, 2000, p. 121).

Em outras palavras, a possibilidade de caminhar em direção a uma sociedade de iguais através de um ethos mínimo passa, necessariamente, pelo político. Ou seja, é preciso superar as tão enraizadas heranças ibéricas, como o patrimonialismo - que impede a criação de espaços voltados ao bem comum por suas próprias características -, assim como, de igual modo, as práticas surgidas a partir da intensificação dos processos de industrialização, como o populismo - que, através da demagogia, impõe respostas prontas, circunstanciais e passageiras para os conflitos sociais. Somente desta forma será possível aproximar o ideal democrático do real democrático e, enfim, caminhar em direção a uma sociedade de iguais.

\section{CONSIDERAÇÕES FINAIS}

A desigualdade social, no Brasil, não é um fenômeno recente e, se hoje pode ser mais facilmente associada à pobreza e à disparidade de renda entre os cidadãos - bem como a todas as privações sociais que a ausência ou insuficiência de renda acarretam -, no passado este mesmo fenômeno foi caracterizado, sobretudo, por hierarquias estamentais determinadas pelas posições de origem. De outro modo, é possível afirmar que se, no presente, a desigualdade é uma questão mais voltada à redistribuição, já que há um controle desigual sobre os instrumentos que produzem valor, no passado o mesmo fenômeno pode ser observado como um problema mais alinhado ao reconhecimento social que, através da diferença, delimitou papéis sociais bem definidos. Contudo, essas duas formas de desigualdade, cada qual legítima no seu contexto histórico, são, como visto, intimamente ligadas em uma relação de causa e consequência, de modo que, na contemporaneidade, a questão passa a ser, então, não apenas de redistribuição, mas, também, de reconhecimento.

Estes são, pois, os contornos da desigualdade social no Brasil. Como revê-los, buscando, enfim, uma sociedade de iguais? A resposta passa, invariavelmente, pela criação de instituições que, como visto no decorrer deste estudo, aproximem o Estado da sociedade e vice-versa, criando espaços públicos voltados ao bem comum, delimitado por um ethos mínimo que demande não apenas reconhecimento, mas, também, redistribuição. 
Nesse sentido, importante frisar que não se trata de instituições que reconheçam todos os indivíduos a partir da afirmação de suas características identitárias - como negro, homossexual ou mulher, por exemplo - mas, sim, como iguais que, como tal, devem receber, em níveis de paridade, as mesmas condições para a própria autorrealização enquanto indivíduos. Tal condição corresponde ao ethos mínimo, necessário no caminhar para uma sociedade de iguais, e deve, necessariamente, ser ambivalente. Reconhecimento sem redistribuição - e viceversa - não basta.

Contudo, em que pese o fato de o Brasil ser um país democrático, plano possível para a realização desta empreitada, também pesa o fato de nossas características, herdadas ainda do Brasil Colônia, mostrarem-se como importantes obstáculos a este intento, como o patrimonialismo, além de outras peculiaridades, estas incorporadas ao plano político já na fase moderna do Brasil, como o populismo. No primeiro caso, a idealização do bem comum é barrada pela apropriação do público pelo privado, inviabilizando a construção de um ethos voltado ao reconhecimento e à redistribuição. No segundo, as projeções mágicas e demagógicas, sempre rápidas na ânsia de atender o interesse popular e manter ou ampliar as bases políticas, se tornam inócuas diante de um problema tão grave e, ao mesmo tempo, de causas tão opacas como as que se desenham, hoje, no Brasil.

Evidenciar esses entraves, por fim, não serve ao propósito de acenar para uma espécie de limite à democracia e, menos ainda, desacreditá-la. Afinal, como vimos, pensar soluções em busca de uma sociedade de iguais implica, necessariamente, pensar a partir do modelo democrático. As deficiências brasileiras no plano político são, afinal, problemas a que estão sujeitas todas as democracias reais, cujos objetivos devem ser, sempre, a aproximação das democracias ideais, modelos que, em essência, já correspondem, na possibilidade de se trilhar o longo e histórico caminho dos direitos, enfim, a uma sociedade de iguais.

\title{
SOCIAL INEQUALITY AND DEMOCRACY: BRAZILIAN CASE AND THE LONG ROAD IN SEARCH OF AN EQUAL SOCIETY
}

\begin{abstract}
The present study sought to analyze the social inequality in Brazil, projecting from the mechanisms of legitimating of this phenomenon, possible alternatives in search of a more just and egalitarian society, reflecting, therefore, one of the founding principles of the democratic State of law. To this end, this article is divided into three parts: the first search to analyze the phenomenon of inequality from his relationship with democracy, in which seat regime Brazil from the legal reorganization proposed by the Constitution of 1988. The second part looks at democracy in Brazil in front of features like populism, this scheme from the mid 20TH century-1930 with the fast-paced growth of the large cities - and its relationship with social inequality. Finally, in the third part of this study, this article rehearses possibilities of construction, from the democracy itself, a society, in fact, composed of the same. For the realization of the present research it was used as a method of the deductive approach, in which it requested from the analysis of categories considered to be fundamental for the development of the theme - such as constituent elements of
\end{abstract}


social inequality in Brazil - and then tackle the problem itself. As a method of procedure it was used the comparative, seeking to investigate the gaps between the democracy ideal and real democracy. As research technique it was applied to literature, based on indirect documentation, which formed the theoretical basis for the development of the study

Keywords: Social Inequality; Democracy; Populism; Recognition; Distribution.

\section{REFERÊNCIAS}

BARROS, Ricardo Paes de. (et. al). A queda recente da desigualdade de renda no Brasil. Rio de Janeiro: IPEA, 2007. Disponível em: http://repositorio.ipea.gov.br/bitstream/11058/1745/1/TD_1258.pdf. Acesso em: 12.07.2014.

BEDIN, Gilmar Antonio. Os direitos do homem e o neoliberalismo. 3 ed. Ijuí: Editora Unijuí, 2002.

Estado de direito e desigualdades sociais: uma leitura da exclusão social a partir da realidade brasileira. In: BONETI, Lindomar Wessler et. al. (Org.). Conceitos e dimensões da pobreza e da exclusão social: uma abordagem transnacional. Ijuí: Editora Unijuí, 2006.

SANTOS, Darlan Machado Santos. Estado de bem-estar social e políticas públicas compensatórias: uma análise da política de bolsa família no município de Ijuí. In: BEDIN, Gilmar Antonio (Org.). Cidadania, Direitos Humanos e Equidade. Ijuí: Unijuí, 2012.

BIELEFELDT, Heiner. Filosofia dos Direitos Humanos: fundamentos para um ethos de liberdade. Tradução de Dankwart Bernsmüller. São Leopoldo: Unisinos, 2000.

BOBBIO, Norberto. O futuro da democracia. Tradução de Marco Aurélio Nogueira. São Paulo: Paz e Terra, 2000.

A Era dos Direitos. Tradução de Carlos Nelson Coutinho. 13 reimp. Rio de Janeiro: Elsevier, 2004.

BOMFIM, Manoel. A América Latina: Males de origem. Rio de Janeiro: Topbooks, 2005.

BRAGATO, Fernanda Frizzo. Direitos humanos além da lógica formal do princípio da igualdade: uma leitura a partir do princípio da não discriminação. In: STRECK, Lenio Luiz; ROCHA, Leonel Severo; ENGELMANN, Wilson (Orgs.). Constituição, Sistemas Sociais e Hermenêutica: Anuário do Programa de Pós-Graducação em Direito da Unisinos/Mestrado e Doutorado, n. 10. Porto Alegre: Livraria do Advogado; São Leopoldo: Unisinos, 2013.

BRASIL. Constituição Federal. Brasília: Senado Federal, 1988. Disponível em: $<$ http://www.planalto.gov.br/ccivil_03/constituicao/constituicaocompilado.htm>. Acesso em: 16.09. 2014.

CARVALHO. José Murilo de. Os bestializados: o Rio de janeiro e a república que não foi. São Paulo: Companhia das Letras, 1987.

Cidadania no Brasil: o longo caminho. 3 ed. Rio de Janeiro, 2002. 
CHAIA, Vera. A longa conquista do voto na história política brasileira. 2010. Disponível em: http://www.pucsp.br/fundasp/textos/downloads/O_voto_no_Brasil.pdf. Acesso em: 04.07.2014.

COSTA, Emília Viotti da. Da Monarquia à República: momentos decisivos. 5 ed. São Paulo: Editora Brasiliense, 1987.

DAHL, Robert. A democracia e seus críticos. Tradução de Patrícia de Freitas Ribeiro. São Paulo: WMF Martins Fontes, 2012.

FAORO, Raymundo. Os donos do poder: formação do patronato político brasileiro. 5 ed. São Paulo: Globo, 2012.

FERREIRA, Francisco. Os determinantes da desigualdade de renda no Brasil: luta de classes ou heterogeneidade educacional? Rio de Janeiro: Pontifícia Universidade Católica de Rio de Janeiro, 2000. Disponível em: http://www.empreende.org.br/pdf/Programas\%20e\%20Pol\%C3\%ADticas\%20Sociais/Desigualdade\%20de\%2 Orenda\%20no\%20Brasil.pdf. Acesso em: 02.05.2014.

FRASER, Nancy. Da redistribuição ao reconhecimento? Dilemas da justiça numa era "pós-socialista”. Tradução de Julio Assis Simões. In: Cadernos de Campo, n. 14/15, 2006. Disponível em:

http://scholar.google.com.br/scholar?cluster=10006775427791380785\&hl=pt-BR\&lr=lang_pt\&as_sdt=0,5. Acesso em: 04.09.2014.

FURTADO, Celso. Formação econômica do Brasil. Rio de Janeiro: Editora Fundo de Cultura, 1959.

HOLANDA, Sérgio Buarque de. Raízes do Brasil. 11 ed. Rio de Janeiro: José Olympio Editora, 1977.

IBGE. Síntese de Indicadores Sociais 2013: uma análise das condições de vida da população brasileira. Rio de Janeiro: IBGE, 2013a. Disponível em: http://biblioteca.ibge.gov.br/d_detalhes.php?id=266778. Acesso em: 10.01.2014.

LEFORT, Claude. Pensando o político. Ensaios sobre democracia, revolução e liberdade. Tradução de Eliana M. Souza. Rio de Janeiro: Paz e Terra, 1991.

MARQUES, Carlos Euclides. Filosofia Política II. Palhoça: Unisul, 2010.

MARQUES, Rosa Maria; MENDES, Aquilas. O social no governo Lula: a construção de um novo populismo em tempos de aplicação de uma agenda neoliberal. In: Revista de Economia Política, v. 26, n. 1, p. 58-74, 2006. Disponível em: http:/ /www.scielo.br/pdf/rep/v26n1/a04v26n1.pdf. Acesso em: 19.08.2014.

MEDEIROS, Marcelo. A trajetória do Welfare State no Brasil: papel redistributivo das políticas sociais dos anos 1930 aos anos 1990. Brasília: IPEA, 2001. Disponível em: http://repositorio.ipea.gov.br/handle/11058/2058. Acesso em: 05.08.2014.

MINISTÉRIO DA EDUCAÇÃO. Índice de Desenvolvimento da Educação Básica 2013. Disponível em: http://ideb.inep.gov.br/resultado/resultado/resultadoBrasil.seam?cid=313769. Acesso em: 12.09.2014.

NEVES, Angela Vieira. A Assistência Social: do discurso à prática profissional - as Representações dos Assistentes Sociais da Legião Brasileira da Assistência. Dissertação de mestrado. Rio de Janeiro: Pontifícia Universidade 
Católica do Rio de Janeiro. 1994. Disponível em:

http://www.neppos.unb.br/publicacoes/Dissertacao\%20Angela\%20Vieira\%201994.pdf. Acesso em: 05.08.2014.

ONU. Declaração Universal dos Direitos Humanos: Adotada e proclamada pela resolução 217 A (III) da Assembleia Geral das Nações Unidas em

10 de dezembro de 1948. Brasília: 1998. Disponível em:

http://www.mp.ma.gov.br/arquivos/CAOPDH/Declara\%C3\%A7\%C3\%A3o_Universal_dos_Direitos_Hum anos_com_introdu\%C3\%A7\%C3\%A3o.pdf.Acesso em: 16.09.2014.

PINKER, Steven. Os anjos bons da nossa natureza: Por que a violência diminuiu. Tradução de Bernardo Joffily e Laura Teixeira Motta. São Paulo: Companhia das Letras, 2013.

POCHMANN, Márcio. Velhos e novos problemas do mercado de trabalho no Brasil. Porto Alegre: Fundação de Economia e Estatística, 1998. Disponível em:

<http://revistas.fee.tche.br/index.php/indicadores/article/view/1297/1665>. Acesso em: 01.04.2014.

PRADO Jr., Caio Prado. Formação do Brasil Contemporâneo. São Paulo: Editora Brasiliense, 1963.

História econômica do Brasil. 22 ed. São Paulo: Editora Brasiliense, 1979.

RIBEIRO, Darci. O povo brasileiro: a formação e o sentido do Brasil. São Paulo: Companhia das Letras, 2006.

ROSANVALLON, Pierre. La sociedad de iguales. Buenos Aires: Manantial, 2012.

SÁ, Nicanor Palhares. Política educacional e populismo no Brasil. São Paulo: Cortez \& Moraes, 1979.

SALES, Teresa. Trama das desigualdades, drama da pobreza no Brasil. Tese de livre-docência. Campinas: Unicamp, 1992.

SEN, Amartya. Desenvolvimento como liberdade. Tradução de Laura Teixeira Motta. 1 reimp. São Paulo: Companhia das Letras, 2010.

El valor de la democracia. Tradução de Javier Lomelí Ponce. Espanha: Editorial El Viejo Topo. s/d.

SOBOTTKA, Emil Albert. Democracia e desigualdade social. In: BOMBASSARO, Luiz Carlos; KRÜGGELER, Thomas; SOUZA, Ricardo Timm de (Orgs.). Democracia e inclusão social: desigualdade como desafio para a sociedade e a igreja no Brasil. Porto Alegre: Edipucrs, 2009.

SORJ, Bernardo. A democracia inesperada: cidadania, direitos humanos e desigualdade social. Rio de Janeiro: Jorge Zahar Editor, 2004.

A nova sociedade brasileira. Rio de Janeiro: Jorge Zahar, 2000.

SOUZA, Jessé. A ralé brasileira: quem é e como vive. Belo Horizonte: Editora UFMG, 2009.

SOUZA, Ricardo Luiz de. Populismo, mobilização e reforma. In: Sociedade e cultura, v. 7, n. 2, 2004. Disponível em: https://www.revistas.ufg.br/index.php/fchf/article/viewFile/986/1190. Acesso em: 14.08.2014.

TODOROV, Tzvetan. Os inimigos íntimos da democracia. Tradução de Joana Angélica d'Avila Melo. São Paulo: Companhia das Letras, 2012. 
TOURAINE, Alan. Crítica da Modernidade. Tradução de Elia Ferreira Edel. 10 ed. Petrópolis: Vozes, 2012.

VICENTINO, Cláudio. A criação do Brasil capitalista. In: DEL PIORI, Mary et. al. (Org.). 500 anos de Brasil: histórias e reflexões. São Paulo: Scipione, 1999.

WEFFORT, Francisco Corrêa. O populismo na política brasileira. 5a ed. Rio de Janeiro: Paz e Terra, 2003.

WIEVIORKA, Michel. A democracia à prova - Nacionalismo, Populismo e Etnicidade. Tradução de António Monteiro Neves. Lisboa: Instituto Piaget, 1993.

YAZBEK, Maria Carmelita. Classes subalternas e assistência social. 7a ed. São Paulo: Cortez, 2009.

Trabalho enviado em 19 de janeiro de 2015.

Aceito em 17 de março de 2015. 